\title{
Las prácticas
}

\section{LA RELIGIOSIDAD CATÓLICA DE LOS AFRODESCENDIENTES DE BUENOS AIRES (SIGLOS XVIII-XIX)}

POR

\author{
Miguel Á. Rosal \\ Conicet-Inst. Ravignani
}

\section{RESUMEN}

El presente estudio pretende indagar sobre la temática de las diversas manifestaciones de la religiosidad católica de buena parte de la comunidad afro de Buenos Aires durante las postrimerías del período colonial y las primeras décadas del lapso independiente. En ese sentido hemos analizado su integración en las distintas cofradías porteñas y los diferentes aspectos religiosos dimanados de los testamentos de morenos y pardos, una de las principales fuentes utilizadas en la pesquisa. También haremos mención a las demostraciones religiosas en el seno de las Asociaciones Africanas que nos ilustran sobre diferentes formas de la religiosidad popular.

PALABRAS ClAVE: Afroargentinos, Buenos Aires, siglos XVIII y XIX, testamentos, religiosidad, cofradías.

\section{«THE CATHOLIC RELIGIOSITY OF THE AFRO-DESCENDENTS OF BUENOS AIRES (18TH AND 19TH CENTURIES)»}

\begin{abstract}
This study has the purpose of inquire about different kinds of catholic religious statement of a part of Buenos Aires's african community during the last days of colonial period and first decades of independent one. We have analyzed their ways of integration to lay brotherhoods and religious aspects founded in african and mulattos wills as the principal source used in this work. We also
\end{abstract}


mention religious manifestations inside African Societies that illustrate us about different ways of popular religiosity.

KEY WORDS: Afro-Argentines, Buenos Aires, 18th and 19th Centuries, Wills, Religiosity, Lay Brotherhoods.

Recibido/Received 12-02-2008

Aceptado/Accepted 30-03-2008

El presente estudio pretende indagar sobre la temática de las diversas manifestaciones de la religiosidad católica de buena parte de la comunidad afro de Buenos Aires durante las postrimerías del período colonial y las primeras décadas del lapso independiente. En ese sentido hemos analizado su integración en las distintas cofradías porteñas y los diferentes aspectos religiosos dimanados de los testamentos de morenos y pardos, una de las principales fuentes utilizadas en la pesquisa: la mortaja, el funeral, el lugar de enterramiento, las mandas forzosas, las mandas voluntarias (entre las cuales no se deben olvidar la fundación de capellanías), y las devociones que se vislumbran a través de la antroponimia ${ }^{1}$. También mencionaremos las demostraciones religiosas en el seno de las Asociaciones Africanas que nos ilustran sobre diferentes formas de la religiosidad popular.

Ya en otros trabajos habíamos realzado el valor que tienen los testamentos como fuente histórica -aunque no siempre apreciados en su justa dimensión por los estudiosos de la institución esclavista- dada la innumerable cantidad de datos -entre otros, nombre del otorgante, su naturaleza y/o vecindad y/o residencia, su filiación, su estado de salud, su estado civil, su descendencia, su estado patrimonial (bienes propios y/o gananciales, deudas, créditos, etc.), sus herederos, su grado de alfabetización- que podemos extraer de la lectura y análisis de esta fecunda documentación ${ }^{2}$.

Pero quizá lo más importante, por medio del testamento se ordenaban las cuestiones temporales en función del bien espiritual del testador, reflejándose

\footnotetext{
${ }^{1}$ Para la recolección de estos documentos, asentados en los Protocolos Notariales, hemos revisado la serie íntegra de los registros de escribanos desde 1750 hasta 1860. Debemos aclarar, sin embargo, que unos pocos no han podido ser examinados, en algunos casos por estar fuera de consulta para su restauración -que en realidad no sabemos si podrá lograrse dada la labor destructiva de la humedad-, como por ejemplo los años 1828 y 1829 correspondientes al registro 2, y en otros por haber, sencillamente, desaparecido, como los años 1855 y 1856 del registro 9. La información se completó con datos provenientes de, entre otros acervos, las Sucesiones. Tanto unos como otras se hallan depositados en el Archivo General de la Nación, en Buenos Aires.

2 Miguel Ángel RosAL, «Diversos aspectos relacionados con la esclavitud en el Río de la Plata a través del estudio de testamentos de afroporteños, 1750-1810», en Revista de Indias, LVI/206, (eneroabril 1996), pp. 219-235. «Diversos aspectos atinentes a la situación de los afroporteños a principios del período post-revolucionario derivados del estudio de testamentos de morenos y pardos», en Revista de Indias, v. LXVI/237, (mayo-agosto 2006), pp. 393-423.
}

Hispania Sacra, LX

122, julio-diciembre 2008, 597-633, ISSN: 0018-215-X 
de esta forma la significación jurídico-religiosa de estas piezas documentales. En efecto, por un lado, se pagaban deudas, se satisfacían injurias y se evitaban pleitos entre los futuros herederos; por otro, realzando el rasgo piadoso del hecho de testar, se refirmaba la fe católica, se buscaban los intercesores y se encomendaba el alma, expresando los deseos sobre la mortaja, las formas de funeral y entierro, y el lugar de sepultura, y realizando las mandas forzosas y, en especial, las mandas pías voluntarias (limosnas, donaciones, libertad de esclavos, etc.). Tanto la Iglesia -recordemos que muchos de los bienes eclesiásticos fueron recibidos por vía testamentaria, y que por lo tanto no le convenía la muerte intestada- como el Estado, eliminando trabas y formalidades, alentaron el acto de testar ${ }^{3}$.

A través de la investigación, hemos hallado 796 documentos, entre testamentos, poderes para testar, testamentos en virtud de poder, memorias testamentarias y codicilos, si bien en su gran mayoría se trata de testamentos nuncupativos ${ }^{4}$. Debido a que algunos afroporteños otorgaron más de uno, y que se encontraron testamentos recíprocos (de matrimonios y de hermanos), en definitiva son 633 las personas a considerar ${ }^{5}$.

Morir ab intestato -si nos guiamos por la gran cantidad de documentación consultada y los relativamente pocos testamentos de afroporteños hallados-fue la regla y no la excepción para el segmento negro de la sociedad porteña, contrariamente a lo que supuestamente sucedía en el estrato blanco de la misma. Sin embargo, los documentos encontrados nos ilustran sobre una silenciosa lu-

\footnotetext{
3 Sobre el tema se puede consultar, entre otros, a Víctor TAU AnZOÁTEGUI, Esquema histórico del Derecho sucesorio del medievo castellano al siglo XIX, Buenos Aires, 1971. María Isabel SEOANE, Forma y contenido de los testamentos bonaerenses del siglo XVIII. Estudio Iushistoriográfico, Buenos Aires, 1995. «Pervivencia del Derecho Castellano-Indiano en el ejercicio del derecho-deber de testar entre los afroporteños del periodo federal», en XV Congreso Internacional de Historia del Derecho Indiano, Córdoba (España), septiembre 2005. Un salvoconducto al cielo. Prácticas testamentarias en el Buenos Aires indiano, Buenos Aires, 2006. «Mirada sobre una minoría poblacional a través de los protocolos notariales. Los afroporteños en el Buenos Aires federal», en Revista Electrónica del Instituto de Investigaciones «Ambrosio L. Gioja», año I, n 1, Invierno 2007, pp. 192-214. Para el ámbito rural bonaerense, ver a María Elena BARRAL, De sotanas por la Pampa. Religión y sociedad en el Buenos Aires rural tardocolonial, Buenos Aires, 2007. En cuanto a Córdoba, consultar la obra de Ana María MARTíneZ de SÁNCHEZ, Vida y «buena muerte» en Córdoba en la segunda mitad del siglo XVIII, Córdoba, 1996. Alejandra Bustos Posse, Piedad y muerte en Córdoba (siglos XVI y XVII), Córdoba, 2005. Para el caso de Santa Fe ver a Teresa SuÁrEZ, «El discurso del morir. Testamentos de primera mitad del siglo XVIII en Santa Fe colonial», en Estudios Sociales. Revista Universitaria Semestral, año IV, $n^{\circ} 7$, Santa Fe, Universidad Nacional del Litoral, $2^{\circ}$ semestre 1994, p. 83-93.

${ }^{4} \mathrm{~A}$ los hallados, se han agregado 11 documentos fechados antes de 1750 y 1 después de 1860; tenemos, además, noticias indirectas de 12 testamentos, pero que aún no han podido ser encontrados y de 8 que al final de la escritura se expresa «no pasó» y que no han sido considerados.

${ }^{5}$ Al final del trabajo, en un apéndice, se halla la lista de los testadores afroporteños citados en el mismo, y la fuente de donde se extrajo el documento.
} 
cha por la integración practicada por una fracción considerable de la comunidad afrodescendiente de Buenos Aires, logrando una mejor adaptación a las pautas culturales, socio-económicas e ideológicas de la sociedad en la cual estaban inmersos, producto de lo cual alcanzan en casi todos los casos a ser propietarios de inmuebles, y en algunos, incluso, amo de esclavos y aceptan, a veces con fervor, la religión del blanco ${ }^{6}$.

\section{COFRADÍAS RELIGIOSAS AFROPORTEÑAS}

Durante el período colonial, la agrupación del segmento negro de la sociedad en cofradías religiosas - como uno de los signos distintivos de la religiosidad católica afroamericana- alcanzó pleno desarrollo en toda Hispanoamérica 7 . Las cofradías -que en la documentación colonial rioplatense también recibían la denominación de «hermandades», mientras que las que estaban bajo el control de los jesuitas se conocían como «congregaciones»- eran esencialmente asociaciones religiosas laicas que tenían como objetivo primordial la ayuda mutua entre sus miembros -en especial el auxilio espiritual para lograr la salvación del alma, pero llegado el caso, también la asistencia material-, si bien existieron motivaciones complementarias, al utilizarlas como espacios de socialización, en búsqueda de una identidad ${ }^{8}$.

Se agrupaban, en especial, bajo alguna advocación de la Virgen María (Nuestra Señora del Rosario, de la Merced o del Carmen eran las preferidas), del Santísimo Sacramento y de aquellas relacionadas con el más allá, las de Ánimas o San José, el patrón de la Buena Muerte - no obstante que funcionaron las dedicadas a otros santos-, para venerar dogmas, verdades teológicas o misterios de la religión católica. Surgieron en la Edad Media, y a partir del si-

\footnotetext{
${ }^{6}$ Este tema ya lo hemos tratado en, entre otros trabajos, «Negros y pardos propietarios de bienes raíces y de esclavos en el Buenos Aires de fines del período hispánico», en Anuario de Estudios Americanos, LVIII/2, Sevilla, (julio-diciembre 2001), pp. 495-512.

${ }^{7}$ A la temática en cuestión nos hemos referido en diversos trabajos, entre ellos: «Religiosidad católica afroporteña. La participación de negros y pardos en las cofradías de Buenos Aires, siglos XVIIIXIX», Silvia C. Mallo y Beatriz I. Moreyra, Miradas sobre la historia social argentina en los comienzos del siglo XXI, Córdoba, Centro de Estudios Históricos «Prof. Carlos S. A. Segreti» Unidad Asociada al CONICET - Centro de Estudios de Historia Americana Colonial - CEHAC Facultad de Humanidades y Ciencias de la Educación. Universidad Nacional de La Plata, 2008, pp. 281-300. «Los afrodescendientes de Córdoba y Buenos Aires y su integración en cofradías religiosas, siglos XVIIIXIX», proyecto editorial correspondiente al PIP 6408-CONICET «Procesos amplios, experiencia y construcción de las identidades sociales. Córdoba y Buenos Aires, siglos XVIII-XX», (en prensa).

${ }^{8}$ Tal como lo expresa Martínez de Sánchez «la cofradía [fue] una corporación laica en cuanto a su constitución, pero religiosa en cuanto a sus fines expresos -ya que los tácitos, como la socialización, se ubican en un segundo plano formal aunque primero en lo informal». Ana María MartínEZ de SÁNCHEZ, Cofradías y obras pías en Córdoba del Tucumán, Córdoba, 2006, p. 184.
}

Hispania Sacra, LX

122, julio-diciembre 2008, 597-633, ISSN: 0018-215-X 
glo XII la modalidad más extendida fue la cofradía gremial. Desde España fueron trasladadas a América, donde alcanzaron un gran desenvolvimiento, tanto entre los españoles, como entre los indios y, como hemos dicho, la comunidad afrodescendiente, siendo el mismo un fenómeno más urbano que rural.

En cuanto a las hermandades de indígenas y de afroamericanos -si bien no podemos perder de vista su finalidad religiosa-, una de las intenciones primordiales que perseguían las autoridades coloniales, tanto civiles como eclesiásticas, al permitir el funcionamiento de este tipo de agrupaciones, era el control de las masas dominadas, de allí su tolerancia, e incluso, su fomento. Claro está que no siempre fue así, pues el fantasma de las rebeliones negras invariablemente estaba presente, tal como sucedió en la ciudad de México hacia fines del siglo XVI, amenaza que frenó la iniciativa de fundar una cofradía de negros 9 .

Existió una amplia diversidad de cofradías -cofradías de devoción, hospitalarias, de ánimas, de redención de cautivos, de conversos, para restablecer las sedes episcopales, regionales, constructoras, étnicas, de clérigos, profesionales, militares, penitenciales, sacramentales, etc.- ${ }^{10}$, las cuales se regían por sus propias constituciones. Dado que la pertenencia a este tipo de agrupaciones significaba prestigio y privilegios -materiales y espirituales-, las personas, de cualquier raza o sexo, en ocasiones se afiliaban a más de una cofradía ${ }^{11}$.

Como anticipamos, los socios de las cofradías solían recibir tanto asistencia material como espiritual. En cuanto a la primera $-y$ teniendo en cuenta que uno de los principales ingresos de estos grupos correspondía al ramo de las limosnas-, las asociaciones solían otorgar créditos, dotes para desposarse o ingresar en los conventos, y, en ocasiones, una especie de jubilación o pensión vitalicia -especialmente si se trataban de cofradías gremiales- para los cofrades que por razones de edad o accidentes no podían trabajar, o habían perdido su fortuna; otras daban hospedaje a viajeros pertenecientes a agrupaciones homónimas.

Respecto a la asistencia espiritual, ofrecían indulgencias, lo cual, para una sociedad profundamente religiosa y practicante como la de los siglos coloniales, no era poca cosa. La preocupación por el destino final siempre estaba presente. El católico de la época tenía conciencia que el acceso directo al paraíso celestial era casi imposible para el hombre común, y que el paso previo por el Purgatorio, similar al

${ }^{9}$ Luis MARTínez FerRer, «El doctor Pedro López y la catequización de los negros de la ciudad de México. El 'memorial suelto' del doctor López al tercer Concilio de México (1585)», en Mar Oceana, $n^{\circ}$ 11-12, Madrid, 2002, pp. 209-217.

10 Ana Mónica GonZÁlEZ FASANI, «Religiosidad y elites porteñas: la cofradía de la Limpia Concepción en Buenos Aires a principios del siglo XVII», en Noveno Congreso Nacional y Regional de Historia Argentina, Buenos Aires, 1996, (separata), p. 2

11 Tampoco debemos perder de vista que muchos creían que «se sumaban para su alma los beneficios por los sufragios y plegarias que ofrecían los miembros por sus hermanos». Alejandra BuSTOS Posse, Piedad y muerte en Córdoba..., cit., p. 186. 
Infierno salvo por el hecho de que su estadía no sería eterna, era prácticamente inevitable, dependiendo la duración del mismo del comportamiento durante su vida terrenal. El ingreso a las cofradías -que «aseguraba la última morada material, en cuanto a la sepultura que tenían asignada dentro de la iglesia, y ayudaba a lograr la definitiva del alma, apoyados por los rezos de sus hermanos en altares especialmente dedicados a ellos»- fue muchas veces el atajo elegido para acortar la permanencia en el lugar de los tormentos, al beneficiarse con las indulgencias -plenarias y parciales- que los Papas concedían a los afiliados a dichas hermandades ${ }^{12}$.

Sin embargo, el cofrade también tenía obligaciones para con la asociación, entre las que se contaba el pagar un canon en concepto de luminaria. Si no lo hacían durante cierto periodo, podían ser expulsados de grupo, de la misma forma que si un integrante fallecido tenía deudas, la cofradía no le celebraba los funerales ni lo sepultaban en el lugar destinado a los afiliados hasta tanto los familiares o el albacea saldase lo adeudado.

Poco después de la segunda fundación de Buenos Aires comenzaron a surgir las cofradías en la ciudad; el total de las establecidas en la jurisdicción porteña ascendió, entre la ciudad y la campaña, a unas 35 asociaciones ${ }^{13}$. Existían, como en toda Hispanoamérica, una variada gama de ellas, incluidas militares, clericales y aquéllas pertenecientes a colectividades de diversas regiones de España.

Un modo de acercarnos a la problemática de las cofradías porteñas ha sido el análisis de sus constituciones en cuanto a la admisión de afiliados, observando que algunas eran más abiertas que otras. La Cofradía de los Humildes de Santa María del Socorro, establecida en el Convento de La Merced hacia 1743, permitía el ingreso de «toda clase de personas así eclesiásticas, como seculares de ambos sexos, sin distinción de calidades, esto es, Españoles, Negros, Indios, Mulatos, ni otras castas», aunque los esclavos debían tener «la licencia [...] de sus Amos»14.

De todos modos, algunas exigían a los aspirantes a ingresar una «calificada limpieza de sangre y calidad». Es el caso de la Cofradía del Santo Cristo del Perdón y Sufragio de las Benditas Ánimas del Purgatorio, con sede en la iglesia

12 Ana María Martínez de SÁnchez, «La Orden de la Merced de Redención de Cautivos en Córdoba del Tucumán. Sus cofradías y la Tercera Orden», en Páginas sobre Hispanoamérica Colonial. Sociedad y cultura, 3, Buenos Aires, 1996, p. 38. Ana Mónica GonZÁlez FASANI, «Religiosidad y élites porteñas...», cit., pp. 3-4.

13 Patricia Fogelman, «Coordenadas marianas: tiempos y espacios de devoción a la Virgen a través de las cofradías porteñas coloniales», en Trabajos y Comunicaciones, $2^{a}$ época, $\mathrm{n}^{\circ}$ 30/31, La Plata, 2006, pp. 118-138.

14 Archivo General de la Nación (en adelante AGN), IX-31-8-5, Justicia, legajo 47, expediente 1363, ff. 5-5v; en la transcripción de documentos de ha modernizado la ortografía. Los cofrades de esta asociación debían llevar permanentemente un escapulario, el cual tenía un navío bordado. Ricardo GonzÁlez, «Aseados y Devotos. Tres cofradías de Negros en Buenos Aires Colonial», en Ricardo GonZÁlez, Imágenes de la Ciudad Capital. Arte en Buenos Aires en el Siglo XVIII, La Plata, 1998, p. 92 .

Hispania Sacra, LX

122, julio-diciembre 2008, 597-633, ISSN: 0018-215-X 
parroquial de San Nicolás de Bari, y el de la Cofradía del Señor San José y Sufragio de las Almas de los Difuntos del Campo Santo del Real Hospital Betlemítico $^{15}$. Aun en una fecha tan tardía como 1857, las constituciones reformadas de la Cofradía de Ánimas Benditas del Purgatorio, establecida en la Parroquia del Pilar en 1774, especifican que «las personas de ambos sexos, que hayan de ser admitidas $[\ldots]$ sean $[\ldots]$ libres de toda raza» ${ }^{16}$.

Otra forma de aproximarnos al fenómeno de las cofradías religiosas afroporteñas ha sido, como hemos anticipado, a través del análisis de los testamentos de morenos y pardos.

Desde el punto de vista de nuestro estudio, las cofradías más interesantes son la del Rosario -de Menores, con sede en la iglesia del convento de Santo Domingo, la del Socorro, en la iglesia de La Merced, la de San Benito, la de Santa Rosa de Viterbo, y la de San Francisco Solano, la tres asentadas en la iglesia del convento de San Francisco, la Hermandad de Ánimas de la iglesia de Montserrat, y, por último, la de Jesús Nazareno en la iglesia de San Juan Bautista, dado que todos los afroporteños otorgantes de testamentos afiliados a cofradías se reparten entre estas siete instituciones, a excepción de Bartola Altolaguirre, negra, que no indica la cofradía a la cual pertenece, si bien ordena que para sus funerales deben «aplicarse cincuenta misas en Santo Domingo y cincuenta en San Francisco».

Hemos observado que del total de 633 otorgantes, 216 declaran pertenecer a alguna cofradía, y de ellos, 17 están afiliados a dos, y 2 a tres de estas agrupaciones, por lo que el resumen es el siguiente:

Negros y pardos afiliados a cofradías religiosas porteñas, siglos XVIII-XIX

$\begin{array}{lr}\text { Cofradía del Rosario } & 108 \\ \text { Cofradía de Santa Rosa } & 49 \\ \text { Cofradía del Socorro } & 33 \\ \text { Cofradía de San Benito } & 31 \\ \text { Cofradía de San Francisco Solano } & 9 \\ \text { Hermandad de Ánimas de Montserrat } & 3 \\ \text { Cofradía de Jesús Nazareno } & 3 \\ \text { no se indica } & 1 \\ \text { total } & 237\end{array}$

\footnotetext{
${ }^{15}$ Ana Mónica GonZáLEZ FASANI, «El espíritu cofradiero en el Buenos Aires colonial (siglos XVIIXVIII)», en Hilda Raquel ZAPICO (coord.), De prácticas, comportamientos y formas de representación social en Buenos Aires (s. XVII-XIX), Bahía Blanca, 2006, pp. 261-295; en este trabajo, la autora ha estudiado varias cofradías de élite.

${ }^{16}$ Citado por María Elena BARRAL, «Iglesia, poder y parentesco en el mundo rural colonial. La cofradía de Ánimas Benditas del Purgatorio, Pilar. 1774», en Colección Cuadernos de Trabajo, nº 10, Luján, 1998, pp. 15-56.
} 
Los estudios llevados a cabo hasta ahora indicarían que en Buenos Aires no existieron cofradías integradas exclusivamente por negros y/o pardos, si bien hacia 1630 el padre Francisco Vázquez Trujillo, sacerdote jesuita, habla vagamente de los deseos de la Orden de establecer «una Congregación o Cofradía de los Negros», lo cual se habría logrado gracias a la sacrificada labor del padre Lope de Castilla, ya que confeccionó un diccionario titulado «Arte y Vocabulario de la lengua de Angola» y de esa forma «se les hablaba en su lengua»17. Y hacia mediados de la centuria, según una carta anua del padre Juan Pastor, «florecen las cofradías de indios y morenos» ${ }^{18}$.

Ya en el siglo XVIII, entre las elegidas por los afroporteños se encuentra, como hemos visto a través de los testamentos, la del Rosario, a los que deberían sumarse aquéllos afiliados que murieron intestados y que, posiblemente, fueron muchos, como por ejemplo José Antonio Cora, negro, cofrade del Rosario $^{19}$. Esta asociación recibía, según la documentación consultada, distintas denominaciones: «Rosario de los humildes», «Rosario de los pardos», «Rosario de los morenos», «de los negros del Convento de Santo Domingo», «del Rosario, orden de menores», «de naturales del Santísimo Rosario», etcétera.

Hay algunos ejemplos ilustrativos. Juana Pinedo, negra, pide ser sepultada en Santo Domingo ya que es cofrade «de su venerable orden tercera», y Manuel Gutiérrez, pardo, indica que es hermano «de la orden tercera del Rosario»; es posible que se estén refiriendo a la cofradía y no a la orden tercera de los dominicos propiamente dicha, pues el acceso a esta clase de agrupación, por ser más estrictas y por su mayor jerarquía espiritual, no debe haber sido nada fácil para la gente «de color» ${ }^{20}$. En ese sentido, Mar-

\footnotetext{
${ }_{17}$ Guillermo Furlong S. J., Historia del Colegio del Salvador y de sus irradiaciones culturales y espirituales en la ciudad de Buenos Aires, 1617-1943, Buenos Aires, 1944, t. 1: 1617-1841, pp. 75 y 489.

18 Cayetano Bruno S. D. B., Historia de la Iglesia en la Argentina, v. III, (1632-1686), Buenos Aires, 1968, pp. 146-147.

${ }^{19}$ AGN, Sucesión 5344, 12 de julio de 1796.

${ }^{20}$ Sobre el tema, ver el trabajo de Roberto DI StÉFAnO, «Orígenes del movimiento asociativo: de las cofradías coloniales al auge mutualista» (capítulo I: 1776-1860), en Roberto DI STÉFANO et alii, De las cofradías a las organizaciones de la sociedad civil. Historia de la iniciativa asociativa en Argentina, 1776-1990, Buenos Aires, 2002, p. 34. Rosángel Vargas presenta el caso de una afrovenezolana tercera de San Francisco. Rosángel VARGAS, «El mundo espiritual de los pobladores de la provincia de Venezuela. Aproximación a través de los testamentos del siglo XVIII», Boletín de la Academia Nacional de la Historia, t. XC, no 359, Caracas, (julio-septiembre 2007), p. 146. También para Ouro Preto -marco de una sociedad mestizada, no sólo desde el punto de vista étnico, sino también si la consideramos desde lo cultural y lo social-se consignan casos de negrodescendientes integrantes de terceras órdenes. Lara MANCuso, «Mining Brotherhoods: Lay Catholic Associations in Brazil and Mexico, 18 ${ }^{\text {th }}$ Century», Jahrbuch für Geschichte Lateinamerikas. Anuario de Historia de América Latina, Band 44, 2007,pp. 126 y 131.
}

Hispania Sacra, LX

122, julio-diciembre 2008, 597-633, ISSN: 0018-215-X 
garita Vicuña, parda, expresa lo siguiente: «hermana tercera que soy de la cofradía del Rosario» ${ }^{21}$.

De todos modos, en nuestros estudios sobre la época colonial ya habíamos advertido que dentro de la misma podía observarse una variada mixtura racial ${ }^{22}$. Pedro Astorga, indio, natural de la ciudad de Puno, declara en su testamento ser cofrade del Rosario, y deja como heredera a su mujer, la negra Isabel, otra de nuestras testadoras, también integrante de la misma agrupación, y para después de la muerte de su esposa, instituyó como heredera a la citada cofradía ${ }^{23}$. La agrupación -como sucedía en otras, como por ejemplo en las de San Benito y la del Socorro- también incluía personas de raza blanca ${ }^{24}$. En su testamento, el presbítero don José Tomás Gaete «Canónigo Honorario y Cura Rector de la Parroquia de Nuestra Señora de La Piedad, Clérigo Domiciliario de este Obispado», solicita como funerales «solo aquellos que corresponda hacer a las Hermandades de Ánimas [y Señor de la Buena Muerte] de Monserrat, del Carmen en la Concepción, del Rosario de los Morenos en Santo Domingo, y de San Benito en San Francisco, de las cuales soy hermano» 25 . Don Pedro Iñigues deja sus funerales «a la disposición de la venerable Orden Tercera de Nuestro Padre Santo Domingo, siéndolo también de las cofradías del Rosario, Carmen, Santos Lugares, San Benito, San Solano y Ánimas» ${ }^{26}$. El presbítero don Saturnino Rodríguez ordena que sus funerales tengan lugar en Santo Domingo y se declara hermano de las cofradías de Nuestra Señora del Carmen, de la del Señor San José y de la de Nuestra Señora del Rosario de Menores «a las que respectivamente se les entregará quinientos pesos moneda corriente para ayudar a los dichos funerales» ${ }^{27}$. Doña Manuela Gómez de Calzadillas expresa: «en cuanto a mi funeral será el de la tercera orden en la Iglesia de Santo Domingo, con cincuenta misas, y el día que los hermanos morenos del Rosario me hagan el suyo

21 También el testamento de María Francisca Ferreira es algo confuso en su redacción: la otorgante pide ser sepultada en San Francisco «como hermana de la tercera orden de San Benito, la mortaja ha de ser de la misma orden».

${ }^{22}$ Miguel Ángel RosAL, «Algunas consideraciones sobre las creencias religiosas de los africanos porteños (1750-1820)», en Investigaciones y Ensayos, n 31, Buenos Aires, 1984, pp. 369-382.

${ }^{23}$ Lucas Tapia y Alarcón, de quien ignoramos su calidad, pero es «natural de Copacavana en la Provincia de La Paz», y está casado con Rafaela Florentina de Usedo, parda, es Hermano Mayor de la Cofradía de San Francisco Solano.

${ }^{24}$ Este tema también ha sido tratado por Osvaldo OTERO, «De esclavos a mercaderes, amos y otros. Redes sociales de la plebe. Algunos miembros de la cofradía de naturales del Santísimo Rosario, convento de Santo Domingo de Buenos Aires en tiempo tardo-coloniales», Montevideo, Seminario Estudios sobre la cultura afro-rioplatense. Historia y presente, 2003, (formato CD).

25 AGN, Protocolos Notariales (en adelante PN), registro (en adelante r.) 3, 1846-1847, f. 12v., 22 de enero de 1847.

${ }^{26}$ AGN, PN, r. 5, 1842-1843, f. 38, 9 de marzo de 1842.

27 AGN, PN, r. 4, 1848, f. 212v., 16 de agosto de 1848. 
se acumularán diez misas más, pidiendo y suplicando a mis albaceas no alteren en lo más mínimo estas disposiciones» ${ }^{28}$.

De otras instituciones supuestamente integradas por afrodescendientes, poco conocemos, tal el caso de la cofradía de Santa María del Corvellón (iglesia de la Merced) ${ }^{29}$. Sabemos que, a fines del siglo XVIII, se intentó fundar la cofradía de San Crispín y Crispiniano por parte de los maestros zapateros «de color», pero no prosperó ${ }^{30}$.

Es posible que la cofradía afroporteña por excelencia haya sido la de San Baltasar, en la iglesia de la Piedad, agrupación que de todos modos, permitía la afiliación de indios y en sus constituciones deja un resquicio para admitir el ingreso de «los señores españoles» ${ }^{31}$, aunque por ser frecuentada principalmente por esclavos ${ }^{32}$, no parecería haber sido, en principio, muy atractiva para estos últimos, ni tampoco para los negros de condición libre, pues en la misma iglesia en que funcionaba la de San Baltasar se fundó, en 1783, «la cofradía de ánimas de la Piedad instituida por los morenos libres», según reza el capítulo $1^{\circ}$ de su reglamento ${ }^{33}$.

Es llamativo, en todo caso, que los promotores de la hermandad, el negro libre Ventura Patrón, entre otros, solicitaron que la cofradía llevara el nombre de la patrona de la iglesia, La Piedad, pero el redactor de los estatutos y cura de la parroquia, don Francisco Javier de Zamudio, optó por el de San Baltasar. Conflictos con los curas de esta parroquia hicieron que la asociación se trasladara a la iglesia del Hospital de los Betlemitas a principios del siglo XIX ${ }^{34}$.

Cabe destacar que nuestro lapso en estudio comienza antes de la creación de la cofradía de San Baltasar (1772) y termina después de su disolución (1856), y que ninguno de los otorgantes de testamentos pertenece a dicha institución ${ }^{35}$. Se

28 AGN, PN, r. 6, 1860, f. 336v., 20 de agosto de 1860.

${ }^{29}$ Manuel SAnguinetTi, San Telmo, su pasado histórico, Buenos Aires, 1965, p. 315.

${ }^{30}$ AGN, IX-30-7-4, Interior, legajo 55, expediente 5, f. 37 y siguientes.

31 «No serán admitidos los señores españoles a no ser que respecto de alguno, por especial inclinación y beneficios hechos a la hermandad, si a la junta de oficiales y al padre capellán les pareciere conveniente, podrá ser admitido». AGN, IX-31-8-5, Justicia, legajo 47, expediente 1365, f. $2 \mathrm{v}$.

32 AGN, IX-31-4-6, Justicia, legajo 17, expediente 436, f. 5v.

${ }^{33}$ AGN, IX-31-4-2, Justicia, legajo 13, expediente 306, ff. 3-6v. Aquí debemos recordar que la casi totalidad de los testadores eran de condición libre y gran parte de los mismos, propietarios de inmuebles y/o de esclavos, etc., lo que marcaba diferencias legales y socioeconómicas lo suficientemente notorias como para que la capa superior de los afroporteños quizá buscara afiliarse a cofradías de mayor rango que las frecuentadas por esclavos. De todos modos, cabe agregar, tampoco hemos hallado afiliados a «la cofradía de ánimas de la Piedad instituida por los morenos libres».

${ }^{34}$ Ricardo GonZÁLEZ, «Aseados y Devotos. Tres cofradías de Negros...», cit., pp. 82 y 95.

${ }^{35}$ La única mención a esta agrupación es la de Francisco Asensio, quien señala que tiene un pleito por dinero con la cofradía de San Baltasar, aunque no indica que sea o haya sido miembro de la misma; es más, Francisco Asensio aparece en otro documento como ex-mayordomo «de la Cofradía de Nuestra

Hispania Sacra, LX

122, julio-diciembre 2008, 597-633, ISSN: 0018-215-X 
ha aducido que los integrantes de San Baltasar, precisamente por su condición de esclavos, no tenían bienes materiales para legar y por lo tanto no tenía sentido que testaran. Sin embargo, no sólo hemos encontrado documentación sobre esclavos propietarios de inmuebles, sino incluso de otros esclavos, además de algunos testamentos otorgados por siervos ${ }^{36}$. Por último, las personas, aun «sin tener bienes materiales que adjudicar [testaban] por la sola consolidación espiritual que ese hecho producía» ${ }^{37}$.

Si bien estas instituciones eran esencialmente asociaciones religiosas laicas, en Santo Domingo y según la opinión de Javier Laviña ${ }^{38}$, para el cual «fueron un elemento primordial en la formación de la etnicidad y desarrollaron una cultura de resistencia», las formas de catolicismo practicadas dentro de las mismas fueron bastante heterodoxas, al punto que habrían servido para preservar vigentes cultos afroamericanos ${ }^{39}$. Carmen Mena García, en cambio, en sus estudios sobre las cofradías de Panamá, sugiere que dentro de ellas se habría producido una paulatina, pero eficiente tarea de sincretismo religioso, y a la postre, de «desculturización» casi completa ${ }^{40}$.

Las investigaciones en curso sobre el tema para la ciudad de Buenos Aires, por el momento corroborarían este último criterio, y probablemente no podría ser de otra forma, pues como hemos visto, los afroporteños otorgantes de testamentos que se afiliaron a alguna cofradía no lo hicieron en entidades étnicamente cerradas, sino en aquéllas que habían dado cabida a distintos grupos raciales.

Madre y Señora del Socorro del extinguido convento de la Merced de esta ciudad». AGN, PN, r. 4, 1823, f. 284, 27 de noviembre de 1823. De la documentación consultada, además, sólo se hace referencia al santo en cuestión en el testamento de la negra africana Luisa Ramírez, quien señala que ha hecho encargos al albacea «respecto a los santos de mi devoción que lo son San Baltazar y el Sagrado Corazón de Jesús». Manuel Duarte, por su parte, oriundo de África, expresa: «soy uno de los miembros principales de la Sociedad de San Baltasar que tienen sufragios de la Nación Conga»; se trata de una Asociación Africana bajo el título de «Hermandad de San Baltasar» y no de la Cofradía. Al respecto ver AGN, X-31-11-5, Policía, Sociedades Africanas, 1845-1864, documento n ${ }^{\circ} 10$.

${ }^{36}$ Como por ejemplo, los de Asencia Manrique, Manuel Solveira y José Pascual Sosa.

37 Ana María Martínez de SÁnchez, Cofradías y obras pías..., cit., p. 155. También para la Santa Fe colonial Teresa Suárez expresa «en una sociedad [...] de escasos recursos económicos, la práctica de otorgar testamento no lleva por principal fin la transmisión de los bienes», sino que tiene indudables connotaciones religiosas. Teresa SUÁREZ «El discurso del morir...», cit., p. 85.

38 Javier LAVIÑA, «Sin sujeción a justicia: Iglesia, cofradías e identidad americana», en Estrategias de poder en América Latina, Barcelona, 2000, pp. 151-163.

${ }_{39}$ Un juicio similar se puede observar en Herbert S. KLEIN, La esclavitud africana en América Latina y el Caribe, Madrid, 1986, pp. 149-150.

40 Carmen Mena García, «Las Hermandades de Sevilla y su proyección americana: estudio comparativo de la Cofradía de Nuestra Señora de los Ángeles o 'de los Negritos' de Sevilla y de la Cofradía de Santa Ana de Panamá», en Estrategias de poder en América Latina, Barcelona, 2000, pp. 129-150; «Religión, etnia y sociedad: cofradías de negros en el Panamá colonial», en Anuario de Estudios Americanos, t. LVII, nº 1, Sevilla, (enero-junio 2000), pp. 137-169. 
De 633 otorgantes de testamentos, 216, es decir el 34,12\%, estaban afiliados a cofradías religiosas; sin embargo, al separar el lapso en dos periodos -el colonial y el independiente, haciendo un corte en 1810-, se pudo observar que en el primero, de 196, 145 se agrupaban en dichas instituciones, el 73,98\%, mientras que en el segundo lapso, de 437 testadores, solamente 71, el 16,25\%, integraba alguna de estas agrupaciones. Parecería, entonces, confirmarse la tendencia, señalada en otras investigaciones, que indicaba que, durante el período post-revolucionario, habría comenzado a disminuir paulatinamente la participación del grupo afro en cofradías religiosas, dentro del marco de una época proclive a la laicización ${ }^{41}$, a la vez que iba aumentando su integración en las llamadas «Asociaciones Africanas». Volveremos sobre el tema.

\section{Aspectos RELIGIOSOS Dimanados DE los TESTAMENTOS: MORTAJA, FUNERAL, LUGAR DE ENTERRAMIENTO, MANDAS FORZOSAS Y CAPELLANÍAS}

A través de la investigación hemos observado que, en general, existía una correlación entre la cofradía a la cual se pertenecía, la mortaja que se escogía y el lugar de enterramiento elegido. Los de la cofradía del Rosario pedían ser amortajados con el hábito de Santo Domingo y enterrados en la iglesia del convento; los del Socorro preferían el hábito de la Merced y ser sepultados en la iglesia respectiva, sede a su vez de la cofradía; los que se repartían entre las cofradías de San Benito, San Francisco Solano y Santa Rosa de Viterbo optaban por la iglesia del convento de San Francisco y el hábito del seráfico ${ }^{42}$.

En cuanto a la elección de la mortaja, de todos modos, se empiezan a notar cambios a medida que avanzamos en el período. En efecto, se fue perdiendo la costumbre, firmemente arraigada en la época colonial, de utilizar como mortaja

${ }^{41} \mathrm{Al}$ respecto se puede consultar nuestro trabajo «Negros y pardos en Buenos Aires, 1811-1860», en Anuario de Estudios Americanos, t. LI, n 1, Sevilla, 1994, pp. 179-181. Fogelman documenta el proceso de secularización y la declinación de las cofradías a lo largo del siglo XIX. Patricia FogELMAN, «Coordenadas marianas: tiempos y espacios de devoción...», cit..

42 Las excepciones que más llamaron la atención fueron, entre otras, las de María Josefa Betolasa, la cual pide ser sepultada en la Iglesia de Nuestra Señora de las Mercedes y «amortajada con el sagrado hábito de su instituto no obstante de ser cofrade del Santísimo Rosario»; la de Francisco José Tompson, natural de Guinea, cofrade del Rosario y que escoge como lugar de enterramiento la iglesia del convento de Santo Domingo y ser «amortajado con el hábito de la Religión de la Rl. y Militar orden de Ntra. Sra. de la Merced»; y la de María de los Dolores Arce, la cual escoge el hábito del Carmen como mortaja y es miembro de la de San Benito, al punto que pide ser enterrada delante del altar del santo en la iglesia del convento de San Francisco. Asimismo, cuando se cambiaba de cofradía, también variaba la mortaja y el lugar de enterramiento, tal como sucedió con Ignacio Falcón, natural de Congo, primero cofrade del Rosario y luego de San Benito, y con María Teresa Bargas, también natural de Congo, que de la cofradía del Socorro pasó a la de San Benito.

Hispania Sacra, LX

122, julio-diciembre 2008, 597-633, ISSN: 0018-215-X 
hábitos religiosos (se pensaba que esto santificaría a los fallecidos, siendo más codiciados aún los que habían sido usados por clérigos ${ }^{43}$ ), y hacia el final del lapso, la cuestión se empezó a dejar a disposición de los albaceas, o directamente no se hacían especificaciones sobre el particular.

Casi todos los otorgantes dejan las formalidades del funeral al arbitrio de los albaceas, si bien algunos piden que se realicen en determinadas iglesias, y otros hacen precisas disposiciones sobre el asunto. Cayetano Díaz, negro «de origen portugués», cofrade del Rosario, y la parda María del Carmen Sosa, cofrade de Santa Rosa, piden que en su funeral «acompañe el cura y sacristán de la Parroquia con la cruz alta»44; Gregoria Carranza, parda, y María Sevicos, negra africana, por el contrario, solicitan que asistan con la «cruz baja». María Mercedes Rojas, ordena 100 misas el «día de las honras», e Isidro Duarte, si bien deja todo en manos de sus albaceas, aclara que se debe evitar «todo lujo» ${ }^{45}$. María Francisca Ascuénaga, «negra libre de nación Angola» y cofrade del Rosario, pide que

«el día de mi entierro, si fuese hora cómoda [es decir, no de noche] y si no al siguiente, se me diga una misa cantada con vigilias por mi alma, como asimismo cuatro rezadas, sin que en esta disposición se entienda entrar los funerales que por sus hermanos acostumbra hacer la cofradía».

Mariana Martínez, oriunda de Angola, demanda que se hagan tres misas por su alma: la primera a la Santísima Trinidad, la segunda a María Santísima, y la tercera a su Santo Ángel de la Guarda y a San José. Mateo Navarro, negro de Mozambique, encargó a sus albaceas

«no se me haga otro funeral que el que me corresponde como hermano que soy de la Cofradía del Santísimo Rosario de Menores en la Iglesia de Santo Domingo donde tengo pagadas las anualidades respectivas para la verificación de mi entierro, aplicándose algunas misas rezadas por el bien de mi alma, según lo permitan mis cortos bienes».

Sobre los costos de los funerales, algunos legajos de las Sucesiones son bastante ilustrativos. La sucesión de la ya mencionada María del Carmen Sosa es bastante minuciosa: se invirtieron en su funeral y entierro 211 pesos y 4 reales, de los cuales 6 pesos 4 reales fueron en cera, 30 pesos en las posas y cruz con

${ }^{43}$ Alberto David LeIVA, «Testamentos mendocinos de los siglos XVI a XVIII a través de un muestreo documental», en Revista del Archivo General de la Nación, n 5, Buenos Aires, 1976, p. 83.

${ }^{44}$ Rosángel Vargas también señala pedidos similares por parte de afrovenezolanos. Rosángel VARGAS, «El mundo espiritual de los pobladores de la provincia de Venezuela...», cit..

${ }^{45} \mathrm{La}$ ausencia de boato en las exequias y entierro fue a menudo requerida por los testadores: Manuel Aguirre, oriundo de África, pide ser sepultado en el cementerio general de católicos «en la zanja destinada para los pobres, mi cadáver conducido en el carro igualmente de pobres, y puesto en el mismo cajón que trae dicho carro». 
que se enterró, 42 pesos en los sufragios de entierro, siete misas rezadas, responso y mortaja, 86 pesos 6 reales en los ropajes, luto de los hijos y de la otorgante, 1 peso se le dio al sacristán, y otro se utilizó para abrir la sepultura. La de María Micaela San Martín y Gutiérrez (para la cual no sabemos con precisión su calidad, pero sí sabemos que es sobrina carnal del pardo Narciso San Martín), señala que en marzo de 1802 se pagaron 18 pesos por la mortaja, 24 pesos por el entierro y doce misas, y 36 pesos por los derechos de cruz alta, dalmáticas, seis posas y cera de mano ${ }^{46}$. Había también otros gastos conexos: el albacea de la parda María Josefa Luque, don Manuel Rodríguez de la Vega, tuvo que desembolsar «dos pesos para azúcar, yerba, y demás gastos precisos en el velorio de su cuerpo desde el día 20 [de noviembre de 1774] que falleció hasta el 21 que se enterró.»

Respecto a los lugares de sepultura, cabe destacar lo sucedido a principios del siglo XIX en la iglesia del convento de Santo Domingo. Francisco de los Santos, negro, tesorero de la cofradía del Rosario, presenta una queja al prior del convento, fray Gregorio Torves, dado que, por un lado, los entierros de los cofrades no se hacen en la iglesia sino en un campo santo pegado a la misma, mientras que «los blancos» son sepultados dentro de aquélla, y por otro, la contribución de 200 pesos fuertes anuales que la cofradía debe abonar al convento se sigue aplicando; pide, por lo tanto, que se le exima a la agrupación de pagar o que sus afiliados sean sepultados en la iglesia, petición denegada por el prior pues aduce que

«habiendo llegado a hacerse intolerables los malos efectos de este abuso la indecencia del pavimento, y el fetor del aire, me vi en la dura necesidad de costear un campo santo donde enterrar el mayor numero de los que piden sepultura en nuestra Iglesia, [para agregar que] después de concluido se han enterrado en él promiscuamente negros y blancos» ${ }^{47}$.

Un conflicto similar surgió entre la cofradía de San Baltasar y el cura de La Piedad, el doctor don Francisco Javier de Zamudio. Si bien también tuvo connotaciones económicas, los cofrades declaran su preferencia por ser enterrados dentro de la iglesia «pues logramos el que los hermanos vivos oren sobre las sepulturas de los muertos» 48 .

\footnotetext{
46 Para tener una idea general de lo que significan los costos consignados, podemos señalar que la casa de María Micaela fue tasada en 694 pesos 2 y 1/2 reales, de los cuales 220 correspondían al terreno de 11 varas de frente x 35 varas de fondo, a razón de 20 pesos la vara de frente, mientras que la tasación de su esclavo, Félix, de 55 a 60 años, «enfermo sin habilidad», alcanzó los 180 pesos.

${ }^{47}$ AGN, IX-31-8-7, Justicia, legajo 49, expediente 1419, ff. 4v.-5, 25 de junio de 1805.

48 AGN, IX-31-4-6, Justicia, legajo 17, expediente 436, 27 de noviembre de 1780. Incluso los reos de muerte tenían derecho al entierro en las iglesias; el cadáver de Anastasio Arellano, ajusticiado en Asunción del Paraguay por haber asesinado a su amo, don Francisco Ruiz de Arellano, fue entregado al «Prior del Convento del Señor Santo Domingo, quien le dio eclesiástica sepultura en su sagrada iglesia». AGN, IX-36-5-5, Tribunales, legajo 82, expediente 35, 8 de enero de 1790.
}

Hispania Sacra, LX

122, julio-diciembre 2008, 597-633, ISSN: 0018-215-X 
En realidad los enterramientos en las iglesias y terrenos aledaños a las mismas se habían convertido en un problema insoluble hacia fines de la época colonial. La Corona española había ordenado en varias Reales Cédulas entre 1786 y 1804 la edificación de cementerios alejados de los poblados, para reemplazar los entierros en las iglesias, por cuestiones de salud pública ${ }^{49}$. Sin embargo, el problema no tuvo una rápida solución ${ }^{50}$.

En Buenos Aires, en 1822 el gobierno prohibió, en el marco de las reformas rivadavianas y por motivos de salubridad, los enterramientos en los templos y las misas de cuerpo presente. A partir de entonces, comienza a especificarse, al redactar el testamento, que el entierro debería hacerse en el «cementerio público» o «general de la Recoleta». La construcción del cementerio en un lugar relativamente apartado del centro de la ciudad, contribuyó a subsanar los inconvenientes, y si bien a fines de 1830 Rosas dio marcha atrás respecto a la prohibición de $1822^{51}$, la tendencia ya estaba establecida, como hemos podido verificar en nuestro trabajo de archivo $^{52}$.

${ }^{49}$ Ana María Martínez de SÁncheZ, «Y el cuerpo a la tierra...en Córdoba del Tucumán. Costumbres sepulcrales. Siglos XVI-XIX», en Apuntes, v. 18, nº 1-2, Bogotá, 2006, pp. 8-25.

50 En el caso de Montevideo, por ejemplo, Isidoro de María, refiriéndose a las dos iglesias de la ciudad, señala: «pues ha de saberse que en ambas iglesias no había lugar sino para 214 sepulturas, mientras sucedió que en veinte meses, desde enero de 1789 a septiembre de 1790, se enterraron 510 cadáveres en las 214 sepulturas, resultando de esto que cada cadáver no podía permanecer enterrado sino siete meses, después de los cuales había que procederse a sacarlo para dar lugar a otro nuevo». Isidoro de María, Montevideo Antiguo, 2 tomos, Montevideo, 1976, t. 2, p. 207. María Isabel Seoane indica que desde el $1^{\circ}$ de enero de 1789 hasta el 23 de septiembre del año siguiente se enterraron 544 cadáveres, a los que deben sumarse los de 17 integrantes del Real Cuerpo de Marina y los de 29 pertenecientes a los Regimientos de Infantería de Buenos Aires y al de Dragones de Montevideo. Finalmente, en 1809 se cumplió lo ordenado por la corona española mediante real cédula en el sentido de construir un cementerio alejado de la población. María Isabel SEOANE, «El ejercicio del derecho de sepultura. Sus vicisitudes en el Montevideo de 1790», en Revista de Historia del Derecho «Ricardo Levene», $\mathrm{n}^{\circ}$ 28, Buenos Aires, 1991, pp. 141-154. También en Río de Janeiro se presentaban problemas similares. Corría 1830, tal cual señala Gilberto Freyre, y recién los higienistas comenzaban a preguntarse: “¿Hasta cuándo persistirá la triste prerrogativa de los muertos de envenenar la vida de los vivos?». Finalmente, en 1838, el Código Municipal carioca prohibió en forma absoluta las inhumaciones dentro de las iglesias y de los claustros de los conventos, pero ese tipo de práctica antihigiénica continuó en otras ciudades del Brasil. Gilberto FreYre, Casa-grande y Senzala. Formación de la familia brasileña bajo el régimen de economía patriarcal, 2 tomos, Buenos Aires, 1942, t. II, p. 358.

51 Roberto DI STÉFANO, «Orígenes del movimiento asociativo...», cit., p. 41.

52 El tema del «cementerio ilustrado» ha sido tratado por Martínez de Sánchez a través del caso de la ciudad de Córdoba, la cual «era un enorme camposanto no visible», problema que recién se subsanó con la inauguración obligada del Cementerio San Jerónimo en 1843, ante la mortandad desatada por una epidemia que imponía sepultar presurosamente los cuerpos. Ana María MARTínEZ DE SÁNCHEZ, «Y el cuerpo a la tierra...», cit., pp. 12 y 16. Ver también a Valentina AYROLO, «El espacio de la muerte. Morir y ser enterrado en Córdoba del siglo XIX», ponencia presentada en las Primeras Jornadas Nacionales de Historia Social, La Falda, Córdoba, (mayo-junio 2007). Sobre la cuestión, también de puede consultar a Nadine BéligAnd, «La muerte en la ciudad de México en el siglo XVIII», en Historia Mexicana, 225, v. LVII, n 1, México, (julio-septiembre 2007), pp. 5-52. Jorge LóPEZ FALCón, «Los 
En cuanto al legado de las «mandas forzosas y acostumbradas», generalmente se separaban de los bienes unos pocos reales, uno o dos a cada una de ellas. Para la época colonial hemos visto que las mandas forzosas eran «la conservación de los Santos Lugares de Jerusalén», «la redención de cristianos cautivos», «la fábrica de la Santa Iglesia Catedral», «la Hermandad de María Santísima de los Dolores y Ánimas Benditas del Purgatorio» y «la Esclavitud del Santísimo Sacramento» ${ }^{53}$.

En el período independiente, las mandas bajan a cuatro y los testadores nunca las mencionan. Hemos hallado unos pocos casos de otorgantes -que no eran afrodescendientes- que citan solamente «la conservación de la Casa Santa de Jerusalén, y redención de cautivos cristianos» ${ }^{54}$. El único documento que nombra cuatro mandas forzosas es la memoria testamentaria de don Martín Juan Quiroga, fechada el 4 de marzo de 1845 en el pueblo de San Pablo del Salto, jurisdicción de Buenos Aires, que además de las señaladas, cita el «Hospital de enfermos» y las «Ánimas del Purgatorio»55.

Para el final del período en estudio, la temprana época post-rosista, hemos comprobado que continúan exiguos -teniendo en cuenta las devaluaciones operadas- los montos destinados a las mismas, que además son por «única vez», en especial si los comparamos, por ejemplo, con los que se pagan por los derechos de escritura. Para dar una idea sobre la cuestión, Petrona Catalina Wrigth lega 4 reales a las mandas y paga 200 pesos de derechos, y Catalina Lima destina sólo 1 real y satisface 130 pesos, respectivamente. Sólo hemos encontrado siete testadores que legaron 2 pesos, y otros seis que separaron 5 pesos de sus bienes para las mandas pías forzosas, sobre un total de 146 otorgantes.

entierros en la Venezuela de antaño. Una aproximación a los usos y costumbres que en materia de sepelios, sepulturas y sepultureros, se tenían a fines de la época colonial y albores de la era republicana», en Boletín de la Academia Nacional de la Historia, t. XC, $\mathrm{n}^{\circ} 357$, Caracas, (enero-marzo 2007), pp. 157-171.

${ }^{53}$ Miguel Ángel Rosal, «Diversos aspectos relacionados con la esclavitud...», cit., p. 222.

${ }^{54}$ Por ejemplo, en la memoria testamentaria de don Bonifacio Basualdo, fechada el 26 de enero de 1841 y asentada en una escribanía porteña, si bien el otorgante es natural de Las Conchas, hacendado en el partido de la Villa de Luján y residente en San Fernando de Buena Vista. AGN, PN, r. 3, 18461847, f. 160v.

55 AGN, PN, r. 8, 1854, e/ff. 340v. y 341. Sobre el tema, es interesante destacar el caso de los testadores protestantes; si bien algunos de ellos no mencionan el asunto, don Juan Bresthaüer, natural de Alemania y que pide ser enterrado en el cementerio de su religión, expresa: «lego a las mandas forzosas y de costumbre en testimonio de adhesión a las instituciones del país la limosna de dos pesos a cada una por una sola vez». AGN, PN, r. 6, 1859, f. 329v., 13 de agosto de 1859. Doña Ana María Schreiner -también natural de Alemania-, a su vez, lega a las mandas un peso «cumpliendo en esta parte con las leyes de este país». AGN, PN, r. 6, 1847, f. 200, 12 de octubre de 1847. Por su parte, Lars Rasmusjor, natural del «Reino de Dinamarca», de religión luterana, ordena -menos resignado- «que en el caso que mis bienes deban satisfacer las mandas forzosas que establecen las leyes del país, se de a cada una de ellas la limosna de dos reales». AGN, PN, r. 4, 1836, f. 40, 13 de febrero de 1836.

Hispania Sacra, LX

122, julio-diciembre 2008, 597-633, ISSN: 0018-215-X 
También hay cláusulas precisas para después de las exequias ${ }^{56}$. Antonio Castellanos, negro procedente de Lubolo (o Rubolo) y miembro de la sociedad del mismo nombre, en su segundo testamento, manda se recen 150 misas en los días inmediatos al fallecimiento. La negra Ana María Semo, también proveniente del continente negro, por su parte, expresa:

«declaro que un cuadro que tengo de San Antonio de Padua se entregue [...] en una iglesia y con él doscientos pesos moneda corriente para que en el día del Santo que es el trece de junio y en el año que siga inmediatamente a mi fallecimiento se diga una misa cantada con toda la solemnidad a que pueda alcanzar esa cantidad, pues esto lo hago por la mucha devoción que siempre he tenido y tengo a éste mi santo protector» ${ }^{57}$.

María del Carmen Liceo, natural de África, deja como heredera en segundo lugar a la Cofradía del Rosario, a la cual pertenece, «a cuyos hermanos encargo que lleven la Imagen de Nuestra Señora del Rosario que tengo en mi casa habitación, y la coloquen al lado de Jesús Nazareno con sus dos candeleros que tiene en el altar de nuestra Hermandad», donde se rezarán misas los «días festivos» por su alma «y demás hermanos difuntos de esta Hermandad»58. Manuel Dolores Sarratea, negro africano «de nación Songo», en su testamento de 1810 declara ser cofrade del Rosario; años después, en otro que data de 1843, pide que todos los años se haga «una misa cantada con sermón y responso en el altar de menores y templo de Santo Domingo al Niño Resucitado por mi intención», y encarga «a los mayordomos de dicha cofradía velen sobre el cumplimiento de esta mi disposición».

En otro orden, Pedro Nolasco Rivas, cofrade del Socorro, pide que se separen de sus bienes 100 o 200 pesos, si es que alcanzare, para que, puestos a réditos, se paguen todos los años «la misa de doce y media y una en los tres días de las cuarenta horas de Ntra. Sra. del Socorro en su Iglesia de la Merced». Mariana Caitio, negra, natural de África, ordena a su albacea «mande decir cada tres meses dos misas en la Parroquia de la Concepción, en el altar de la Virgen del Carmen, en beneficio de mi alma y la de mi esposo», las cuales se pagarán con

\footnotetext{
${ }^{56}$ En otros casos, las demandas son más urgentes: Isabel López, «de nación Songo en África», ordena que «inmediatamente se manden decir y aplicar por mi salud espiritual y temporal, si fuere del agrado de Dios Nuestro Señor, cuatro misas a Nuestra Madre y Señora del Carmen, mi abogada e intercesora».

${ }^{57}$ Hacia el final del lapso en estudio, Rufina Pich de Márquez, negra africana, vecina de San Isidro, pero que deja asentado su testamento en una escribanía de Buenos Aires, expresa: «es mi voluntad se diga una misa cantada a Jesús Nazareno en los Ejercicios; se entreguen por mi albacea al Señor Cura de San Isidro trescientos pesos moneda corriente, doscientos de ellos para la función o luminaria de San Isidro y su esposa Santa María de la Cabeza, y los cien restantes para San José del mismo Pueblo».

58 También lega 100 pesos a «la Hermandad de Santa María del Socorro [...] encargando a dicha Hermandad que no se olviden los hermanos de su bienhechora encomendándola a Dios en sus ejercicios y oraciones».
} 
el alquiler de su rancho, debiendo además invertir el resto en la manutención y el buen estado del inmueble para que siempre pueda producir y, por último, deberá pasar el encargo a otra persona para cuando muera. La parda Josefa Allende impuso una pía memoria sobre su casa, o importe de su venta al 5\% anual de réditos, para que se digan cinco misas al año: en el día de San Cosme y San Damián, por el alma de su madre, Damiana Quintana; en el día de San Jorge y en el de San Juan Bautista, en memoria de sus dos maridos; en el día de San José, por su propia alma; y en el de la Purísima Concepción, por el alma de Baleria, una hija natural difunta, encargo hecho a los padres franciscanos. Un caso similar es el de Juana Catalina Díaz, quien ordenó que las misas se rezaran «un viernes de cada mes en el altar de N. Sra. de Dolores de la Iglesia Catedral».

El capitán Fermín de Pessoa ${ }^{59}$, cuarterón esclavo que fue de don Miguel de Riglos (o Riblos), hacia el final de su vida posee un significativo patrimonio que incluye varias propiedades rurales y urbanas -la casa en la que habita, por ejemplo, se sitúa a una cuadra de la catedral-, y un considerable número de esclavos $^{60}$. No sólo fue devoto benefactor de la iglesia del convento de Nuestra Señora de las Mercedes, donde pide ser enterrado, «amortajado con su Sagrado Hábito y Correa», sino que además hizo edificar una capilla dedicada a San Judas Tadeo, inaugurando de esta forma el culto a esta advocación, tradición que perdura hasta nuestros días, y fundando una capellanía que posibilitara celebrar la fiesta anual del santo, y otra más para costear la «del glorioso San Fermín» en la catedral, donde tiene su altar ${ }^{61}$.

Don José Ávalos Ríos, moreno libre, manifiesta, en 1858, que María Feliciana Almeyra, también negra, fallecida, en su testamento del año 1844 había

\footnotetext{
${ }^{59}$ Sobre el tema, ver a Fernando M. MADERO, «El capitán Fermín de Pessoa y su genealogía», en Boletín del Instituto Argentino de Ciencias Genealógicas, tomo VIII, $\mathrm{n}^{\circ} 122$, Buenos Aires, noviembre 1982, pp. 443-449. «Algo más sobre Fermín de Pessoa y su familia», en Boletín del Instituto Argentino de Ciencias Genealógicas, tomo X, $\mathrm{n}^{\circ}$ 138, Buenos Aires, septiembre 1984, pp. 126-127. Abel S. ECHAZu y Hernán Carlos LuX-Wurm, «Nuevos aportes sobre Fermín de Pessoa y su familia», en Boletín del Instituto Argentino de Ciencias Genealógicas, tomo X, $\mathrm{n}^{\circ}$ 140, Buenos Aires, noviembre-diciembre 1984, pp. 209-213. Carlos María Birocco, «Fermín Pesoa, de esclavo a hacendado», en Cuarto Congreso de Historia de los Pueblos de la Provincia de Buenos Aires, Mar del Plata, noviembre de 1993, t. 1, Buenos Aires, pp. 69-82.

${ }^{60}$ En la cláusula $17^{\mathrm{a}}$ del su testamento, el cual firma, expresa «declaro por más bienes míos los muebles que siguen=», mencionando entonces a: Domingo, mulato de 40 años, «capataz de la estancia poblada en la Isla de Escobar»; Juan Anselmo, negro; María y María Teresa, negras, «que sirven en la casa donde vivo»; Antonio, negro de 20 años, de oficio barbero; Matías y José, negros, que «asisten en chacara de la Costa»; Pedro, negro de 60 años, para el cual prohíbe su enajenación dada su avanzada edad; y en la cláusula $47^{\mathrm{a}}$ señala que Santiago, mulato de oficio herrero, «anda fugitivo», y es legado «a Nuestra Señora de la Merced».

${ }^{61}$ Cabe destacar que el hijo de su antiguo amo, el canónigo don Miguel de Riglos, al cual le había pagado buena parte de sus estudios en Córdoba y Chile, le pidió le rebajase la mitad de la cuantiosa deuda que la familia Riglos tenía con él «por misas», lo cual aceptó (cláusula 48a).
}

Hispania Sacra, LX

122, julio-diciembre 2008, 597-633, ISSN: 0018-215-X 
ordenado que «se fundase una capellanía laical y memoria de misas [...] por el bien de su alma y la de su esposo, Antonio Almeyra»; nombró como patronos de dicha capellanía a los albaceas, Miguel Barrios, igualmente negro, y al declarante, en forma mancomunada ${ }^{62}$. Para 1858 Barrios ya ha fallecido, por lo que el compareciente, en nombre de la citada María Feliciana, «funda para siempre en la Iglesia de Nuestra Señora de Montserrat una capellanía puramente laical o memoria de misas a título de patronatos de legos sobre la casa que quedó por muerte de su instituyente.» Deberán decirse cinco misas al año en el altar de Nuestra Señora del Carmen ${ }^{63}$ de la citada iglesia, se deberá mantener el rancho en buen estado, y nombra como patrono sucesor a Juan Fernández, quien a su vez deberá designar a otro que lo suceda luego de su fallecimiento.

Los ejemplos de fundación de capellanías o pías memoria de misas, las que serán aplicadas por las almas de los testadores y, en ocasiones, por las de sus consortes y/o parientes cercanos, abundan ${ }^{64}$. Algunos especifican que la fundación de la capellanía es a perpetuidad, y tomando los recaudos necesarios para que ello suceda, nombran una serie de patronos que deberán cumplir los encargos hechos. El negro José Alisa y Urien ordena que con los alquileres de una de sus dos casas se hagan dos misas por mes, en día sábado, en el altar de Nuestra Señora del Carmen, en la iglesia de San Juan o Monjas Capuchinas de Santa Clara, por su alma, la de su esposa, y las de los padres de ambos. Los patronos serán, en primer lugar, la esposa, Polonia Machado; en segundo, la hija natural

\footnotetext{
${ }^{62}$ AGN, PN, r. 2, 1858, f. 104v., 27 de febrero de 1858. Nótese el tratamiento de «don»; para esta época, es decir hacia el fin de periodo en estudio, no era extraño que algunos afroporteños lo recibieran, a la vez que no se indicara su calidad de afrodescendiente. Es más, sabemos que Ávalos Ríos es «moreno libre» por el testamento de María Feliciana de 1844, pues en la escritura de 1858 no se indica nada al respecto.

$63 \mathrm{Si}$ bien no hemos encontrado afrodescendientes afiliados a la cofradía del Carmen (iglesia de la Concepción), quizá por ser una afrupación más elitista, el culto mariano a dicha advocación parecería haber estado bastante extendido entre los morenos y pardos de Buenos Aires. En efecto, la mencionada Mariana Caitio ordena a su albacea «mande decir cada tres meses dos misas en la Parroquia de la Concepción, en el altar de la Virgen del Carmen.» Rosa Abad, «de nación Banguela», establece que los alquileres de uno de los cuartos de su casa «se inviertan en beneficio y reverencia de Nuestra Señora Madre Señora del Carmen.» De la misma forma, José Alisa y Urien determina que con los alquileres de una de sus dos casas se hagan dos misas por mes, en día sábado, en el altar de Nuestra Señora del Carmen, en la Iglesia de San Juan o Monjas Capuchinas de Santa Clara. María de los Dolores Arce escoge el hábito del Carmen como mortaja. La ya citada Isabel López estipula que «se manden decir [...] cuatro misas a Nuestra Madre y Señora del Carmen, mi abogada e intercesora.» Baleriana Belén, por su parte, posee «dos imágenes de bulto en sus respectivos nichos de Nuestra Señora del Carmen y Nuestra Señora del Rosario».

${ }^{64}$ Serían los casos de la citada María Feliciana Almeyra, «natural de la Costa de África, de nación Qui Pará», quien manda «se funde una capellanía laical y memoria de misas» por el bien de su alma y la de su primer esposo, y, de manera similar, de María Almada, negra africana. Para el caso de Venezuela, Rosángel Vargas presenta un panorama similar. Rosángel VARGAS, «El mundo espiritual de los pobladores de la provincia de Venezuela...», cit., p. 171.
} 
de su esposa, Celedonia; luego una hija de ésta, Octavia Romero; en cuarto lugar, una hermana de la anterior, Loreta, y por último, el monasterio de la Capuchinas. Parte de los alquileres deberán emplearse en las reparaciones de la vivienda, para que «se conserve y perpetúe».

En ocasiones, directamente se nombra como heredera al alma, en especial cuando se trata de personas solteras o viudas sin hijos, mencionándose incluso las almas del Purgatorio, tal cual se puede constatar en los testamentos de la parda Juana Bentura Carmona y de la negra María Palacios ${ }^{65}$, o se instituye como heredera una cofradía, como lo efectúa la negra María Teresa Bargas, integrante de la de San Benito, o Jacinto González, negro, cofrade «del Rosario de los humildes» y de la cual fue mayordomo, quien no sólo dona 25 pesos a la institución, y 50 pesos fuertes, además de dos arrobas de cera, al convento de Santo Domingo, sino que también funda una capellanía. Todas estas prácticas religiosas coadyuvaban a acortar la permanencia del alma en el Purgatorio ${ }^{66}$.

\section{MANDAS PÍAS VOLUNTARIAS, PRÁCTICAS PARTICULARES Y DEVOCIONES DERIVADAS DE LA ANTROPONIMIA}

Resulta bastante obvio que los testadores estudiados eran conscientes de su infamante esclavitud -de hecho, unos pocos todavía lo eran a la hora de otorgar el documento ${ }^{67}$ y en otros casos están casados con personas esclavizadas ${ }^{68}-$, si bien muchos también lo eran de sus orígenes africanos, y aun así aceptaban, a veces con devoción, la religión impuesta por la raza dominante ${ }^{69}$. José Goyena, negro libre, de nación Mina-Ausá declara que es

\footnotetext{
${ }^{65}$ Además de ordenar una misa cantada el día del «dulce nombre de María», y otra rezada el día de «Nuestro Padre San Francisco» por bien de su alma y la de su esposo, si algo sobrare, se deberán celebrar misas «por las benditas ánimas, o por el alma de quien Nuestro Señor Jesucristo quisiera aplicarlas según su santísima voluntad».

${ }^{66}$ Roberto DI STÉFANO, «Orígenes del movimiento asociativo...», cit., p. 38.

${ }^{67}$ Ya hemos citado los casos de Asencia Manrique, Manuel Solveira y José Pascual Sosa.

${ }_{68}$ Tal el caso de Josefa Padín, casada con el negro esclavo Antonio Isasi, o el de Joaquín Lavalle, cuya segunda esposa, Catalina Meyer, se encuentra esclavizada.

69 Don Manuel Eulogio del Pardo, vecino del Pueblo de San Pedro, declara en la cláusula 10 de su memoria testamentaria que posee dos esclavos, Antonio y Juana, a los cuales deja libres «advirtiendo que mi criada Juana para obtener la carta de libertad se ha de confesar y comulgar». AGN, PN, r. 1, 1850, f. 192, 27 de mayo de 1840. Don Joaquín Suárez otorga la libertad futura condicional a su esclavo Antonio Macuá, natural de Mozambique, a partir del $1^{\circ}$ de enero de 1837; entre otras condiciones que impone el amo, tiene «la obligación de enseñar a rezar a los negritos bozales como hasta aquí». AGN, PN, r. 1, 1836, f. 291v., 4 de agosto de 1836. Doña Serafina Henríquez Peña indica en su testamento: «mando y es mi voluntad que mi criado el moreno Domingo [...] el día que se bautizare será libre, otorgándosele por mis albaceas la correspondiente carta de libertad». AGN, PN, r. 1, 1839, f. $398 v ., 1^{\circ}$ de agosto de 1839 . Sobre la evangelización de los esclavos puede consultarse el trabajo de Liliana CRESPI, «Cristianismo y esclavitud. Discusiones sobre la evangelización de los esclavos en Hispa-
}

Hispania Sacra, LX

122, julio-diciembre 2008, 597-633, ISSN: 0018-215-X 
«hijo legítimo (según la costumbre de mi Nación) de padres cuyos nombres ni apelativos recuerdo por que manos tiranas me arrancaron de su ceno hace muchos años y me trasladaron a este país donde me bauticé bajo la protección de mi amo, don Santiago Esposito» ${ }^{70}$.

En ese sentido, y más allá de la florida redacción de algunos notarios porteños $^{71}$, debemos recalcar la integración en las distintas cofradías y la fundación de capellanías o pías memorias, y su preocupación para que las mismas se perpetuaran, como prácticas religiosas que auxiliaban al alma en vistas a un futuro tránsito por el Purgatorio.

También tenemos que subrayar distintas actitudes, por ejemplo, la preocupación por el pago de deudas de, entre otros, Francisca Breques; en su testamento se consigna una fórmula habitual en este tipo de documentos: «declaro que no debo ni me deben poca ni mucha cantidad, pero por ser la memoria frágil, en descargo de mi conciencia, si alguno demandase de mis bienes hasta la cantidad de un peso, es mi voluntad se le abone con solo su juramento y simple declaración, y de ahí para arriba con plena justificación en forma» ${ }^{72}$.

Igualmente debemos mencionar la condonación de deudas; Micaela Cueli, perdona a sus deudores para que esas personas «se acuerden de mi alma, encomendándome a Dios alguna vez», y deja, además, varias cantidades a diversas personas, a «los pobres» y al «Hospital de Mujeres», sumando unos nada despreciables 1.850 pesos de limosnas, una de las tantas variantes de las mandas pías voluntarias.

Los legados a instituciones religiosas, hospitalarias y de caridad, en ocasiones alcanzan cifras significativas. La parda Ramona Fernández destina 500 pesos «a los pobres de la cárcel» y otros tantos a cada uno de los hospitales de la ciudad, además de 200 pesos al Convento de San Francisco y una igual suma a la Iglesia

noamérica», en Memoria y Sociedad. Revista del Departamento de Historia y Geografía, v. 7, $\mathrm{n}^{\circ} 15$, Bogotá, noviembre 2003, pp. 133-144.

70 De todos modos, hemos comprobado que algunos de los testadores africanos recordaban el nombre de sus progenitores, seguramente por haber sido esclavizados en edad adulta. Antonio Basavilvaso, natural de Bambará, declara que sus padres fueron Ayari y Sabe; «los finados Morima y [...] Sipencia Gamcia» lo fueron de Francisco Ascuénaga, «de nación Munchagua»; María Luisa Martínez, «mora», indica que es hija «legítima de los finados cónyuges africanos Yiagambay y Arama»; Dambaba y Gaidó engendraron a Diego Corpet; Cipriano Quisongó y Rosas, natural de Angola, señala que nació de Hualenda Buta y Nahuembo Buta; Adumo y Aguale fueron los progenitores de Juan José Arandia; y, por último, José Mariano López, oriundo de Angola, es hijo de Dara (su padre) y Quima (su madre). Otros otorgantes mencionan el nombre de sus padres africanos ya castellanizados.

${ }^{71}$ El tema de los notarios, como «parte de la escritura de la esclavitud y su memoria» es tratado en Michael Zeuske y Orlando García MartíneZ, «Notarios y esclavos en Cuba (siglo XIX)», Debate y Perspectivas. Cuadernos de Historia y Ciencias Sociales, $\mathrm{n}^{\circ} 4$, Madrid, Fundación MAPFRE TAVERA, diciembre 2004, pp. 127-170.

$72 \mathrm{El}$ subrayado es nuestro. 
de Montserrat. La parda María Josefa de la Higuera, a su vez, efectúa un legado de 1.000 pesos al Hospital de Hombres y otros tantos al de Mujeres, y la misma cantidad «para la cera del Santísimo Sacramento de la Iglesia de Nuestro Padre San Francisco, y [...] para la cera del Santísimo Sacramento de Nuestra Señora de Montserrat [...] a fin de que sirvan estas limosnas en bien y memoria de mi alma y de la de mi hermana Gregoria» ${ }^{73}$. El negro Elías Calderón lega diversas cantidades a los conventos de Catalinas, Capuchinas y Recoletos, a la Santa Casa de Ejercicios, y al Hospital General de Hombres y de Mujeres ${ }^{74}$.

La negra Isabel deja libre a sus esclavos -otra manda pía- Carlota, Paula y Evaristo para «después de sus días», pero por ser menores de edad, los pone bajo la custodia de la «Madre Beata de la Casa de Ejercicios» hasta que tomen estado.

Es interesante el caso de Manuel García, pardo libre, que se hace esclavo de por vida del Santísimo Sacramento, para servirlo en las fiestas del Corpus, octavario, jueves y domingos de Renovación dentro del año, y atender y cuidar los ornamentos y ropa blanca, para lo cual otorga un instrumento declaratorio a favor de la cofradía del Santísimo Sacramento instituida en la iglesia catedral ${ }^{75}$. El pardo Juan Antonio Navarrete, también declara ser «esclavo del Smo. Sto. del Altar y de ntra. madre y Sra. de la Merced» ${ }^{76}$.

Otro ejemplo significativo es el de Feliciana Núñez, parda, cuya hija Francisca «se halla hoy de religiosa profesa en el monasterio de Sta. Catalina de Sena», y aclara que «a la que hoy se halla de monja» le tenía dado el hábito y el ajuar para entrar en el monasterio.

En otro orden, se pueden consignar los libros que declara poseer Juan Bautista Romero, entre ellos «la Biblia en latín con láminas [...], Vida de San Francisco de Sales, El Evangelio en triunfo, Vida de Jesucristo, [...] y otros libritos devotos de meditación».

\footnotetext{
${ }^{73}$ Además pide a sus albaceas que «por el bien de mi alma hagan decir las misas de San Gregorio, y quince misas en memoria de los quince misterios de Nuestra Señora del Rosario en su altar, y una misa de réquiem.»

${ }^{74}$ Entre otros ejemplos, también se pueden mencionar a Escolástica Ituvat, quien manda que el quinto de sus bienes «se emplee todo en Nuestra Sra. de la Nieva» (Nuestra Señora de las Nieves es, junto a San Martín de Tours, patrona de Buenos Aires). Isabel Rodríguez lega 500 pesos «a la Virgen Patrona de la Parroquia de Balbaneda». María Allende dona 50 pesos a la Cofradía de Santa Rosa para «dorar el retablo del altar de la Santa». Por último, Catalina Lima nombra como heredera a la Santa Casa de Ejercicios con la condición de que dicha institución mande decir veinte misas por año por el bien de su alma y las de sus parientes.

${ }^{75}$ AGN, PN, r. 3, 1767, f. 122v., 30 de abril de 1767.

${ }^{76}$ Esta clase de devoción también se repite en Córdoba: en el testamento otorgado en dicha ciudad, Petrona Bracamonte, parda, pide ser enterrada en «la Iglesia de Nuestra Señora de Mercedes con entierro menor rezado y amortajada con su santo hábito que tengo en mi poder, pues soy su cofrada y esclava voluntaria de su cofradía y como tal le he hecho varias veces su fiesta». AGN, IX-15-6-1, Juzgado de Bienes de Difuntos, t. 23, expediente 8, 8 de junio de 1792 .
}

Hispania Sacra, LX

122, julio-diciembre 2008, 597-633, ISSN: 0018-215-X 
La negra Baleriana Belén ${ }^{77}$ posee «dos imágenes de bulto en sus respectivos nichos de Nuestra Señora del Carmen y Nuestra Señora del Rosario». Carmen Maza, negra africana, lega a una de sus herederas y albaceas, Carmen López, «un nacimiento completo de mi propiedad con todas las efigies que lo forman, recomendándole que todos los años continúe haciendo las funciones por la Pascua de Navidad».

La antroponimia, a través del análisis de los nombres de los hijos de los otorgantes, también nos brinda algunas pautas sobre las preferencias piadosas de las personas «de color». Este criterio se fundamenta en que los hijos nacieron en el seno de un hogar católico y posiblemente fueron sus padres quienes eligieron el nombre cristiano, lo que no sucedió con todos los otorgantes, ya que algunos provenían de África. Hemos constatado que entre los nombres de varón prevalecen los de José, Pedro y Juan, y entre los de mujer, el de María, repitiéndose también los de Juana y Josefa, si bien para uno y otro sexo el espectro nominal es bastante amplio.

Durante el período hispánico, habíamos visto que los nombres más repetidos eran los de José y María, indicando posiblemente una especial devoción hacia la Sagrada Familia. Un caso ilustrativo puede ser el de la parda María Mansilla Gaete, que tuvo ocho hijos, entre ellos a María Belén, María de los Santos, María Mercedes, María Isidora, María Josefa y José Mansilla ${ }^{78}$.

$\mathrm{La}$ antroponimia relativa a hijos y nietos de los testadores no revela, sin embargo, predilección alguna por Baltasar o Benito, santos de raza negra; algo similar sucedió con la consulta de los registros de bautismo de la Iglesia de la Piedad entre 1800 y $1820^{79}$.

\section{LAS ASOCIACIONES AFRICANAS}

Nuevos estudios refutan la tesis de que las sociedades africanas fueran instituciones que reunían necesariamente a integrantes provenientes de una misma

77 También María de los Santos Mendiolara, mujer de color oriunda de Córdoba, posee una imagen de Nuestra Señora de La Merced y de un «divino Señor de la Humildad y Paciencia». Por su parte, la parda Victoria Durán, declara, entre otros bienes, «dos candeleros chicos de peltre, que los dejo destinados para el servicio de Jesús Nazareno, en la Iglesia de San Juan»; también lega un «crucifijo grande» a la Cofradía del Socorro, de la cual es miembro. A su vez, la negra María Palacios consigna «un nicho del Señor de la Agonía» y «una imagen de Nuestra Señora de la Concepción de bulto».

${ }_{78}$ Sobre el culto mariano consultar el trabajo de Patricia FogELMAN, «Coordenadas marianas: tiempos y espacios...», cit..

${ }^{79} \mathrm{Al}$ respecto, puede verse nuestro trabajo «Algunas consideraciones sobre las creencias religiosas...», cit., pp. 377-378. 
región del continente negro ${ }^{80}$. Astrid Windus, por ejemplo, piensa que la fundación de una sociedad africana se basaba más en las relaciones sociales que en el origen étnico de sus integrantes ${ }^{81}$. Oscar Chamosa señala que fueron «communities created from a variegated array of individuals with different ethnic backgrounds, languages, lineages, and interests» ${ }^{82}$. El ejemplo más ilustrativo es el caso de los Congos, asociación madre que reunía dentro de sí a pequeños grupos que al entrar en conflicto con aquélla dieron lugar al surgimiento de nuevas sociedades, como la Loango, Musundi, Goyos, etcétera. De hecho existieron asociaciones creadas por afrobrasileros, como la «Bahiana» o la «Brasilera», o por personas de origen desconocido, como la «Argentina Federal».

Entre otras responsabilidades, las sociedades africanas debían prestar ayuda a sus integrantes, como préstamos para la compra de la libertad de los todavía esclavizados y para la adquisición de herramientas de aquellos que eran artesanos, atender a los enfermos y educar a los niños del grupo, y controlar la conducta de los afiliados en bailes y reuniones, e incluso, entregar a los delincuentes de la comunidad a la policía, de la cual dependían las agrupaciones para poder funcionar.

Chamosa, sin embargo, afirma que el objetivo substancial de las sociedades era efectuar una serie de rituales basados en un tema recurrente en las religiones africanas tradicionales: el culto de los antepasados, noción en cierta forma emparentada con elementos del catolicismo, como por ejemplo la idea de la «buena muerte», entendiendo por ancestros a los miembros fundadores de la agrupación ${ }^{83}$.

80 Sobre el tema de las «naciones», «sociedades» y diferentes apelativos que reciben las asociaciones afroporteñas, y las características y funcionamiento de las mismas, consultar a Pilar GoNZÁLEZ BERNALDO de QUIRÓs, Civilidad y política en los orígenes de la Nación Argentina. Las sociabilidades en Buenos Aires, 1829-1862, Buenos Aires, 2001, pp. 103-118. Oscar CHAmOsA, «To Honor the Ashes of Their Forebears: The Rise and Crisis of African Nations in the Post-Independence State of Buenos Aires, 1820-1860», en The Americas. A Quarterly Review of Inter-American Cultural History, v. 59, $\mathrm{n}^{\mathrm{o}} 3$, enero 2003, pp. 347-378.

${ }^{81}$ Astrid WINDUS, «El afroporteño en la historiografía argentina-algunas consideraciones críticas», en Trabajos y Comunicaciones, $2^{a}$ época, $n^{\circ}$ 28/29, La Plata, 2002/2003, pp. 9-41. En ese sentido es ilustrativo el testamento de Catalina Paz, parda, natural de la ciudad de Córdoba, traída por su amo a Buenos Aires cuando ya era mayor, la cual ordena a su albacea «que después que suceda mi fallecimiento y mi cuerpo sea sepultado en sepultura que comprará para ello, cederá el título a la Nación Manfurí, para que sean enterrados en ella, los que siendo libres no tengan donde enterrarse, ni como comprarlas». Para el caso de Río de Janeiro, Carlos Eugenio Líbano Soares, al reseñar el libro de Mariza Carvalho Soares «Devotos da cor: identidad étnica, religiosidade e escravidao no Rio de Janeiro no século XVIII», señala que la autora muestra que esa clase de «identidades» eran construcciones elaboradas por los traficantes de esclavos y que la vida cultural de los oriundos del continente negro durante el periodo colonial era más «filha de seu tempo» que «de sua terra». Cfr. en Tempo, $\mathrm{n}^{\circ} 12$, Rio de Janeiro, Universidade Federal Fluminense (UFF), diciembre 2001, pp. 181-183.

82 Oscar CHAmosA, «To Honor the Ashes of Their Forebears...», cit., p. 376.

${ }^{83}$ Ibidem, pp. 370-372.

Hispania Sacra, LX

122, julio-diciembre 2008, 597-633, ISSN: 0018-215-X 
Hemos podido vislumbrar en la investigación archivística algunas de estas cuestiones. El testamento de Cayetano González, natural de África, fundador y presidente de la «Cofradía Barundí», que, sin duda, se trata de una de estas asociaciones de negros y no de una cofradía religiosa tal cual hemos visto más arriba, nos ilumina respecto de las actividades de estas agrupaciones:

«asimismo declaro que como fundador de la sociedad Barundí, con las licencias necesarias, he adquirido con el provecho de ella, una casa y un terreno, situada en la calle de Córdoba, cuartel 17 [...] y declaro al mismo tiempo que no me quedan más bienes de la citada sociedad por haberlos invertido en las enfermedades y entierros de los socios que han fallecido» ${ }^{84}$.

Joaquina Vivar de la Rosa, perteneciente a «la Sociedad de la Nación Moro», pide en su testamento que se le «hagan los sufragios acostumbrados a todos los paisanos». José Rico, natural «de Guinea, nación Guizama», declara en el suyo que debe 60 pesos «a las Ánimas de mi nación».

A fines del siglo XVIII empezaron a surgir estas agrupaciones. Rosa Palacios, cofrade del Rosario, declara que prestó 100 pesos a la «Cofradía de los Cabundas», de la cual fue fundadora. Pedro Preciado, negro, compra un sitio a don Francisco Villoldo «como hermano de una hermandad de ánimas que arbitrariamente han formado varios negros aunque sin autoridad de juez competente» ${ }^{85}$; según nuestros datos Preciado también fue cofrade del Rosario.

En el siglo XIX, y volviendo al tema de los inmuebles de estas agrupaciones, Félix Bolaños, Felipe Zapiola y Pedro de la Merced, «Mayordomos de la Nación Mondongo», venden a don Martín Jiménez de la Paz un sitio en el barrio de la Concepción, el cual linda con los vendedores y es parte del terreno «de la cofradía de la Nación Mondongo» ${ }^{86}$. En 1822, Ignacio Guzmán, negro, «hermano mayor de la Hermandad de ánimas establecida en la Parroquia de Nuestra Señora de la Concepción», compra un sitio a don Francisco Belgrano; poco después Guzmán declara que el sitio pertenece a la Nación Banguela ${ }^{87}$. Manuel de la Cruz Antecos, negro, compra a doña María de los Remedios Rodríguez un terreno situado en el cuartel 21, calle Independencia, que linda con

\footnotetext{
${ }^{84}$ En otro documento, Cayetano González declara que el 30 de abril de 1828 compró a don Santiago Wilde un sitio, en el cuartel 17, y «que la compra que hizo era para el bien de las ánimas de la Nación Barundí, en cuyo beneficio pasa y traspasa para que del expresado terreno pueda disponer la Sociedad del modo que por bien tenga.» AGN, PN, r. 8, 1830, f. 65v., 19 de abril de 1830. La compra de 1828 no la tenemos registrada pues es probable que esté asentada en el registro 2, que como anticipamos, está fuera de consulta.

${ }^{85}$ AGN, PN, r. 6, 1796, f. 111, 20 de mayo de 1796.

${ }^{86}$ AGN, PN, r. 3, 1817, f. 331v., 2 de diciembre de 1817.

${ }^{87}$ AGN, PN, r. 5, 1821-1822, f. 175v., 3 de julio de 1822 y r. 5, 1823-1824, f. 26,8 de abril de 1823.
} 
sitio de «la Hermandad de Ánimas de la Nación Conga» ${ }^{88}$. Tres lustros después, María Bruna del Rosario de la Cruz y Antecos, negra, hija de Manuel de la Cruz Antecos, vende dicha propiedad, la cual sigue lindando con terreno de «La Hermandad de Ánimas de la Nación Conga» 89 . Don Rafael Macedo Ferreira vende a José Vril, Francisco Estanislao Molina y José López, «el primero como Mayor de la Nación Carabarí, y los otros dos individuos del Cabildo o Junta de la misma Nación, los cuales lo compran con destino para con su producido hacer bien por las almas de la Hermandad dicha», un sitio y rancho en el barrio de Montserrat ${ }^{90}$. Miguel Besares, negro, como representante de la «Sociedad de la Nación Mina», la cual también aparece como «Hermandad de Ánimas», vende a don Fernando Torres un sitio en el barrio de Santa Lucía, la Vieja, «Partido de La Piedad ${ }^{91}$. Dos meses después, Besares adquiere a doña Ana María Rodríguez un sitio en la calle Cangallo (hoy Perón), también en el barrio de Santa Lucía, y lo hace en nombre de la Nación Mina, «para servicio de la Cofradía de Ánimas del Purgatorio» ${ }^{92}$. Vicente Molina, negro libre, declara que el 12 de marzo de 1822 compró un terreno «por orden y dinero [de] la Cofradía de la Nación Guisama»93. Joaquín Lezica, mayordomo de la nación Mina Tacuá, compra a don Marcos Blanco un terreno en Montserrat, «cuyo sitio es para las ánimas» ${ }^{94}$. Domingo Baye, Tomás Mano, Antonio de la Patria y Manuel Camorra, negros libres, mayordomos de la nación Mondongo, compran a don Bernardo Caravajal un sitio en el cuartel 24, calle Europa (hoy Carlos Calvo), para la «Cofradía» de dicha nación ${ }^{95}$. En febrero de 1831, Manuel Alsina, negro, compra a doña Ana Castillo un sitio en la calle San José, el cual linda «con los Tambores de los negros»; meses después efectúa una declaratoria según la cual el dinero era «de la Nación Santé, cuya propiedad pertenece a las Ánimas de la misma Nación, en cuyo beneficio pasa y traspasa» ${ }^{96}$. Don Juan Bautista Fresco vende «a la Hermandad de los morenos de la Nación Ganguela Lumbi», representada por su presidente, Joaquín Pacheco, y el vocal Antonio Riso, un sitio en el barrio de Montserrat ${ }^{97}$.

Estos ejemplos nos hablan de asociaciones diferentes a las cofradías, más informales e independientes del clero, pero con intenciones espirituales similares.

\footnotetext{
${ }^{88}$ AGN, PN, r. 7, 1824-1825, f. 67v., 29 de abril de 1824.

${ }^{89}$ AGN, PN, r. 2, 1840, f. 946v., 30 de noviembre de 1840.

${ }^{90}$ AGN, PN, r. 3, 1825, f. 264, 21 de septiembre de 1825.

${ }^{91}$ AGN, PN, r. 4, 1827, f. 92, 28 de febrero de 1827.

92 AGN, PN, r. 2, 1827, f. 158v., 23 de abril de 1827.

93 AGN, PN, r. 2, 1827, f. 261, 24 de julio de 1827.

${ }^{94}$ AGN, PN, r. 3, 1828, f. 296, 16 de agosto de 1828.

95 AGN, PN, r. 3, 1830, f. 176, 14 de junio de 1830.

96 AGN, PN, r. 8, 1831, fs. 277v. y 492, 11 de febrero y 9 de septiembre de 1831, respectivamente.

97 AGN, PN, r. 4, 1833-1834, f. 5v., 13 de enero de 1834.
} 
Sin embargo, también había que atender lo terrenal. Félix Luis Fonseca, negro, compra a don Francisco Belgrano, un sitio en Concepción «y paraje nombrado el tango de los morenos»98. Cayetano Castro, negro, compra, también a don Francisco Belgrano, un terreno, en el mismo barrio, que linda con el «Tambo de los Banguelas»99. Antonio Arechaga, Mariano Villanueva y Abdón Casavalle, negros, «como mayordomos y principales representantes de la nación Moro», dan su poder especial a Antonio Arana, también integrante de dicha agrupación

«para que gestione, procure y solicite ante el Superior Gobierno de la Provincia les conceda licencia para bailar los días festivos bajo la propia obligación de observar rigurosamente el reglamento que les de el Jefe de Policía o que para tales casos se halle descripto con respecto a las otras Naciones de Guinea.»100

En otro orden, doña Hermenegilda Concha da la libertad a la negra Josefa, de 50 años, soltera, en 100 pesos, cantidad que recibió «de mano del caporal de la Nación Mora, el moreno [ya mencionado] Antonio Arechaga»101. Doña Petrona Camargo libera a la negra Juana en 160 pesos, dinero entregado por el moreno libre Andrés Castellanos, presidente de la Nación Lubolo ${ }^{102}$.

Es decir que, por un lado podemos ver las reminiscencias de los candombes organizados por las «naciones» durante el período hispánico, y por otro, la asistencia mutua entre los asociados al contribuir para la liberación de aquéllos que aún permanecían esclavizados ${ }^{103}$. En síntesis, hacia la época que estamos estudiando «co-

\footnotetext{
98 AGN, PN, r. 1. 1813-1815, f. 6, 20 de enero de 1813.

99 AGN, PN, r. 4, 1822, f. 83v., 10 de abril de 1822.

100 AGN, PN, r. 7, 1824-1825, f. 320, 26 de mayo de 1825.

101 AGN, PN, r. 6, 1824-1825, f. 667v., 21 de noviembre de 1825.

102 AGN, PN, r. 2, 1827, f. 312, $1^{\circ}$ de septiembre de 1827.

103 Cejas Minuet y Pieroni especulan que en el seno de las Naciones también se les daba cabida a
} esclavos fugitivos y veteranos de guerra. Mónica CEJAs Minuet y Mirta PIERONI, «Mujeres en las Naciones afroargentinas de Buenos Aires», en América Negra, no 8, Bogotá, diciembre 1994, p. 138. En otras regiones de Iberoamérica, eran las cofradías religiosas las que tenían un carácter netamente mutualista, plasmado, en especial, en los préstamos pecuniarios concedidos a sus miembros esclavizados para que pudieran obtener la libertad, tal como se expresa, por ejemplo, en las constituciones de la Cofradía de Nuestra Señora de la Regla, de Lima, de mediados del siglo XVII. Jean-Pierre TARDIEU, Les confréries de Noirs et de Mulatres a Lima (fin XVIe-XVIIe siécle), Université de Bordeaux III, 1989, pp. 10-11; ver también el capítulo sobre cofradías en su obra Los negros y la Iglesia en el Perú, siglos XVI-XVII, Quito, 1997, pp. 509-563. La Cofradía de Nuestra Señora del Rosario y Redención de Río de Janeiro, cuyos miembros eran libres y esclavos, negros y mulatos, fue fundada con el propósito específico de ayudar a aquellos hermanos en cautiverio que deseaban comprar su libertad. A. J. R. RUSSEL-WoOD, «Black and Mulato Brotherhoods in Colonial Brazil: a Study in Collective Behavior», en HAHR, v. 54, n 4, noviembre 1974, p. 595. Patricia Mulvey señala, sin embargo, que del estudio de 165 «compromissos» (estatutos o constituciones) de hermandades afros del Brasil, solo en 11 se hacen referencias a la cuestión; de todos modos, algunas cofradías utilizaban sus fondos para ayudar a miembros indigentes, hermanos enfermos o familiares de los afiliados fallecidos. Patricia A. MuLVEY, «Sla- 
fradías» $\mathrm{y}$ «sociedades» coexisten y tienen puntos de contacto en cuanto sus objetivos y funcionamiento, si bien las segundas se multiplicarán a partir de 1823, con la sanción del reglamento de las Sociedades Africanas, mientras que las agrupaciones cofradiales paulatinamente habrían ido perdiendo gravitación.

\section{LAS FORMAS DE LA RELIGIOSIDAD POPULAR ¿SINCRETISMO RELIGIOSOS O AFROCA- TOLICISMO?}

Para algunos estudiosos de la problemática afroamericana, el marco social que significaban las cofradías religiosas y las asociaciones de la gente «de color», habría permitido la conservación de las distintas religiones africanas en el nuevo mundo, o al menos facilitó el desarrollo de un sincretismo entre la religión de los dominadores blancos y los diversos rituales trasladados desde el continente negro. Para el caso concreto de Buenos Aires, sin embargo, son escasas, a nuestro entender, las fuentes ${ }^{104}$ que nos puedan dar luz sobre un sincretismo religioso que, de todas formas, parece haber sido bastante tibio ${ }^{105}$, aun cuando entendemos que todas las religiones son sincréticas, y que el sincretismo no se circunscribe sólo a la religión, abarcando otros aspectos de la cultura ${ }^{106}$.

ve Confraternities in Brazil: Their Role in Colonial Society», en The Americas, A Quarterly Review of Inter-American Cultural History, v. XXXIX, ${ }^{\circ} 1$, julio 1982, pp. 49-52 y 55. Ver también a René RIBEIRO, «Relation of the Negro with Christianity in Portuguese America», en The Americas. A Quarterly Review of Inter-American Cultural History, v. XIV, $\mathrm{n}^{\circ}$ 4, abril 1958, p. 471.

104 Windus sostiene que en las fuentes «son excepcionales los casos que muestran manifestaciones culturales provenientes de determinadas regiones africanas». Astrid WINDUS, «El afroporteño en la historiografía argentina...», cit., p. 29. También Mello e Souza señala «a enorme carencia de registros acerca dos modos de vida dos esclavos no Brasil, especialmente a forma como exerciam sua religiosidade». Marina de Mello e SouZA, «Santo Antonio de nó-de-pinho e o catolicismo afro-brasileiro», en Tempo, $\mathrm{n}^{\circ}$ 11, Rio de Janeiro, julio 2001, p. 184.

105 Visiones diferentes se pueden encontrar en, entre otros, Ricardo RodRíGUEZ MoLAS, «Presencia de África Negra en la Argentina (Etnias, Religión y Esclavitud)», en Desmemoria. Re-Vista de Historia, año 6, n 21-22, Buenos Aires, enero-junio 1999, pp. 33-70. Norberto Pablo CiRIo, «Antecedentes históricos del culto a San Baltazar en la Argentina: La Cofradía de San Baltazar y Ánimas (17721856)», en Latin American Music Review, v. 21, nº 2, Austin, Fall/Winter 2000, pp. 190-214; “¿Rezan o bailan? Disputas en torno a la devoción a san Baltazar por los negros en el Buenos Aires colonial», en Víctor Rondón (ed.), Mujeres, negros y niños en la música y sociedad colonial iberoamericana, Santa Cruz de la Sierra, 2002, pp. 88-100. Daniel SCHÁVELson, Buenos Aires negra: arqueología histórica de una ciudad silenciada, Buenos Aires, 2003. Oscar Chamosa, "To Honor the Ashes of Their Forebears...» cit..

${ }^{106}$ Sobre el tema se puede consultar, entre otros, a Sérgio F. FERRETTI, «Notas sobre o sincretismo religioso no Brasil - modelos, limitações, posibilidades, en Tempo, $\mathrm{n}^{\circ} 11$, Rio de Janeiro, julio 2001, pp. 1326. Ver también a João José ReIs, «Entrevista de Martha Abreu e Ronaldo Vainfas com João José ReIs. «Religiosidade, rebeliao e identidade afro-baiana», en Tempo, $\mathrm{n}^{\circ}$ 11, Rio de Janeiro, julio 2001, pp. 255260; el entrevistado expresa que si pensamos la religión en una «longuíssima» duración, no habría religión que no fuese de algún modo híbrida, en el sentido que no existe práctica cultural pura.

Hispania Sacra, LX

122, julio-diciembre 2008, 597-633, ISSN: 0018-215-X 
Los bailes son señalados como el ámbito natural donde se habrían manifestado estos ritos sincréticos, de allí los «bandos» mediante los cuales fueron prohibidos durante el período colonial. Sin embargo, estas fuentes sólo aluden a «bailes indecentes» $\mathrm{y}$ «juntas» de variada mixtura racial para efectuar «juegos» en lugares más o menos apartados del centro de la ciudad, y deja en claro que «podrán públicamente bailar aquellas danzas de que usan en la fiesta que celebran en esta ciudad» ${ }^{107}$. En aquellos tiempos, además, esta práctica no parece haber gozado de la simpatía de las autoridades eclesiásticas, como demuestra el pedimento del procurador general del cabildo: «el que se suplique al Excelentísimo Sr. Obispo sirva suspender la excomunión que se ha promulgado contra los que bailan absolviendo a todos [...] y para lo sucesivo se la quite y alce enteramente» 108 , exhortación repetida en varias oportunidades.

De todos modos, tampoco el cabildo porteño era partidario de los candombes coloniales. En una representación de su síndico procurador general, don Francisco Ignacio de Ugarte, se constatan las objeciones esgrimidas: «en estos bailes olvidan los sentimientos de la Santa Religión Católica» y «renuevan los ritos de su gentilidad» al efectuar «ciertas ceremonias y declaraciones que hacen en su idioma» 109 .

Los negros de la nación Cabunda presentaron un memorial solicitando no se les prohíba sus bailes públicos los días de fiesta, en un sitio despoblado, junto a la iglesia de Montserrat, en donde perciben limosnas con el «objeto de hacer bien por las almas de sus finados paisanos»; el informe sobre la cuestión, efectuado por el cabildo y elevado al virrey, sin embargo, es negativo «por lo obsceno del baile de los tambos» ${ }^{110}$.

Las agrupaciones cofradiales, sin embargo, tuvieron mayor tolerancia. En mayo de 1786 Manuel Ledesma, negro libre, mayordomo de la cofradía de San Baltasar, alude a las limosnas recolectadas para «las Animas del Purgatorio» en los bailes dominicales ${ }^{111}$. La hermandad, además, se benefició con un «superior decreto concediéndoles la danza honesta con música para que con ella se festejase la solemnidad del octavario de nuestro augusto Patrón», permiso que, de todos modos, duró sólo para el domingo 16 de enero de 1791, pues al domingo siguiente, explican los morenos, el sargento de dragones Elías Bayalá y el negro

${ }^{107}$ AGN, IX-8-10-3, Bandos, f. 79v., 6 de mayo de 1766 y ff. 174v.-175, 20 de septiembre de 1770, bandos de los Gobernadores Cevallos y Vértiz, respectivamente.

108 Acuerdos del Extinguido Cabildo de Buenos Aires, serie 3, t. 1, Buenos Aires, 1926, p. 255, 3 de noviembre de 1752 .

109 Acuerdos del Extinguido Cabildo..., cit., serie 3, t. 8, 1930, pp. 628-629, 19 de septiembre de 1788.

110 Acuerdos del Extinguido Cabildo..., cit., serie 3, t. 9, 1931, p. 221, 23 de diciembre de 1789.

${ }^{111}$ AGN, IX-42-6-3, Tribunales, legajo S-8, expediente 6, f. 7 y siguientes. 
Pablo Agüero «nos hicieron pedazos los instrumentos y nos quitaron la superior licencia de V.E.»112.

En realidad, los incidentes donde estaba involucrado Pablo Agüero, natural de Guinea, eran repetidos, y seguramente no podía ser de otra manera, ya que, según su propia declaración, fue «comisionado por el Señor Gobernador Intendente para prender negros y negras fugitivos de sus amos, y para tenerlos sosegados y quietos en sus diversiones y bailes». Sabemos, por ejemplo, que en una ocasión debió encargarse de «los negros que se estaban vistiendo de Cambunda el día de San Baltasar en la Capilla de la Piedad»113. Su párroco, don Francisco Javier de Zamudio, también tuvo problemas con los negros de la cofradía, a los cuales acusó de «ponerse en el atrio del templo a danzar los bailes obscenos que acostumbran, como ejecutaron el día de San Baltasar a la tarde y el domingo de Pascua de Resurrección», destacando «la bulla que metían con sus alaridos y tambores».

Los morenos se defendieron alegando que no habían sido ellos sino «los hermanos menores del Santísimo Rosario» los que «en el lado de la calle formaron su baile» y sólo «el portabanderas se batió en el atrio en señal de alegría». Agregaban que dichos bailes no podían ser tildados de obscenos pues en ellos no intervenían mujeres, y que además eran conscientes de la «presencia del Santísimo Sacramento y de la efigie de Jesucristo y su Santísima Madre»114.

En el siglo XIX, se puede observar la importancia que las Asociaciones Africanas concedían a los ritos funerarios; en 1847 algunos integrantes de la nación Munyola indagan si se «han empleado aquellos alquileres [de la casa de la agrupación] en las exequias funerarias de los hermanos que han fallecido [...] siendo este deseo tan natural, tan cristiano»115. Oscar Chamosa consigna el estado de cuentas de la Sociedad Musundi para el año 1857, la cual gastó el $48 \%$ de su activo monetario en funerales y misas, y el $83 \%$ de sus ingresos provino de las limosnas durante los funerales de sus socios ${ }^{116}$.

112 AGN, IX-12-9-13, Solicitudes de presos, ff. 87-87v, 23 de enero de 1791.

113 AGN, IX-36-4-3, Tribunales, legajo 74, expediente 10, f. 13v., 24 de enero de 1787. Este expediente se refiere en realidad a ciertos sucesos, en uno de los cuales, supuestamente, Agüero habría intentado coronar al negro Pedro Duarte, mayordomo de la cofradía de San Baltasar, como «rey de los Congos»; luego de tomadas varias declaraciones, incluidas la de los involucrados, por parte del ayudante mayor don Francisco Rodríguez y por orden del señor teniente del rey don Diego de Salas, el primero concluye que es «todo incierto».

${ }_{114}$ AGN, IX-31-4-6, Justicia, legajo 17, expediente 436, f. 10 y siguientes, 18 de mayo de 1779.

115 AGN, X-31-11-5, Policía, Sociedades Africanas, 1845-1864, documento 6.

116 Oscar Chamosa, «To Honor the Ashes of Their Forebears...», cit., p. 373. En el testamento de María Antonia Pan y Agua, negra africana, se consignan varias cantidades bastante significativas, tanto en metálico como en papel moneda, «que se recogieron en limosna para una misa de cuerpo presente que debía celebrarse por el alma de mi finado esposo», a saber: «sesenta onzas de oro, cuatrocientos patacones, treinta y tres medios pesos plata cortada, cuarenta cuatro pesos cortados: más cinco patacones uno y medio reales; cuatrocientos pesos moneda corriente, y noventa pesos ídem».

Hispania Sacra, LX

122, julio-diciembre 2008, 597-633, ISSN: 0018-215-X 
Es interesante destacar las conexiones entre testadores e integrantes de las Asociaciones Africanas. El entrecruzamiento de datos indicaría que las mismas eran frecuentes. El ejemplo más representativo es el testamento (y la sucesión) de Antonio García López, presidente de la Sociedad Maraví, pero también había otorgantes que elegían como albaceas a miembros destacados de la agrupación a la cual pertenecían, como Josefa Portela, quien nombra como segundo albacea a Pedro Videla, «Presidente de la Nación Carabal», o Rosa Avad, cuyo primer albacea es «Don» Joaquín Arriola, presidente de la nación Banguela, o, para finalizar, Juan Buceta, «de nación Guizama», el cual elige como albacea al «presidente de mi nación, José Torres».

Entre la documentación se pueden destacar los testamentos que ilustran -más allá del marcado sentido religioso que se manifiesta en el acto de testarsobre la religiosidad católica de algunos integrantes de las Asociaciones Africanas. José Mariano López, negro africano, pide ser enterrado en el cementerio católico «en una de las sepulturas que tiene la Nación Angola a que él pertenece», y que «se le manden decir misas a la imagen de Dolores que tiene en su cuarto.» De la misma forma, Joaquina de la Patria, oriunda de África, elige «la sepultura de la Nación Munllolo a que pertenece» y deja como heredera a su alma, debiéndose invertir el remanente de sus bienes «en misas y sufragios por ella». Catalina Cerna, que es «nacida en la Costa de África, en la nación Quipara», indica que dicha agrupación le adeuda 100 pesos, legando a su vez una cantidad semejante a «la Santa Casa de Ejercicios», dejando como heredera a su alma ${ }^{117}$. Francisco González, de la Sociedad Barnó, manda fundar una pía memoria en beneficio de su alma y la de su esposa en la iglesia de Montserrat, siendo su patrono «la Sociedad de Africanos de la Nación Barnó». Manuel Sánchez, natural de África, señala que tiene un pleito con los síndicos de su nación, que no consigna, sobre un inmueble, para agregar más adelante que nombra como heredera a su alma «debiendo mis albaceas destinar lo que quede de mis bienes en beneficio del nacimiento del hijo de Dios y de María, la inmaculada Virgen, Nuestra Señora Pura y siempre Concepción».

Sin embargo, sería en las casas donde se reunían las agrupaciones donde se habrían desarrollado rituales mortuorios que indudablemente tendrían origen africano o, al menos, prácticas menos ortodoxas en cuanto a la religión católica. En noviembre de 1845 , la síndica de la nación Wombe, Rosa Cariaga, declara que se ha hecho reparar «la sala de ánimas» de la sede de la mencionada agrupación ${ }^{118}$. Las

117 Este testamento fue revocado «muy particularmente» por otro otorgado casi un año después, dónde no se señalan deudas ni legados, si bien se conserva como heredera al alma. AGN, PN, r. 2, 1849, f. 29, 16 de enero de 1849.

118 AGN, X-33-4-7, Policía, Partes de Ciudad y Campaña, legajo no 49, libro 133, 1844-1845, e/ nº 51 y 52. «Don» José Antonio Díaz - nótese el tratamiento de «don»-, negro libre, Presidente de la Nación «Congo de Columbo», pone en venta junto a otros socios - entre ellos el socio primero, «Don» 
fuentes no aclaran qué era lo que sucedía dentro de estas peculiares habitaciones. Aun así, Chamosa arriesga que quizá se efectuaran velatorios como el descripto por Juana Manzo en un artículo periodístico de 1865: «curioso espectáculo es un velorio de negros en su sitio [...]. Donde al devoto rosario siguen el canto monótono entonado en coro por los dolidos veladores, las danzas fúnebres, los llantos, y que es más cómico, escenas de beberage, peleas, celos, y otra porción de incidentes» ${ }^{119}$.

$\mathrm{Al}$ respecto, hemos hallado un documento en donde se ventila un incidente que involucra a la morena Mercedes del Sar, remitida a la cárcel pública por el alcalde del cuartel 20, Santiago Navarro, el 6 de febrero de 1844. En la mañana del 3 de febrero murió quemada una niña de 4 años, hija de la citada negra «la que se tomó la libertad de velarla en la noche y formar baile hasta el otro día sin haber dado cuenta a la autoridad competente»; al otro día, sí solicitó el permiso para velarla en la noche, lo cual fue denegado, y se le ordenó que sepultara el cuerpo, pero

«ella, en lugar de obedecer lo mandado, se encaminó a convidar porción de morenos, morenas y pardos para que asistiesen al baile que debía tener lugar en la noche en celebridad de la muerte de la desgraciada joven [...] esperó la noche, hora en que empezó a recibir innumerables morenos y morenas que había convidado.»

El alcalde Navarro, acompañado de varios tenientes alcaldes, llegó a la casa, despidió a más de 40 personas «y ordenó que se concluya el baile» ${ }^{120}$.

Hasta aquí las fuentes, no demasiado abundantes, y de las cuales, por supuesto, se hacen distintas interpretaciones. A nuestro entender, algunos de los casos presentados son manifestaciones de lo que podríamos denominar afroca-

Francisco Parejas- un inmueble que habían adquirido para «el cuarto de las ánimas». AGN, PN, r. 4, 1841, e/ff. 62v. y 63, 11 de octubre de 1840.

119 Oscar CHAmosa, «To Honor the Ashes of Their Forebears...», cit., p. 374.

${ }^{120}$ AGN, X-33-4-7, Policía, Partes de Ciudad, legajo no 49, libro 132, nº 72, 1844. De todos modos, es interesante destacar que la negra parece haber sido detenida más por no haber solicitado el correspondiente permiso para efectuar el velatorio -y no haber sepultado a su hija cuando se le ordenó-, que por la singularidad del mismo, lo que llevaría a pensar que esta clase de celebración podría haber sido más o menos habitual en el Buenos Aires de la época. Y aquí no debemos perder de vista que las manifestaciones culturales de los afroporteños, en especial sus bailes, gozaron de plena simpatía por parte del régimen rosista. Sobre el tema, se puede consultar a Maxine HANON, «Las lavanderas, morenas y federales», Todo es Historia, año XXXVII, n ${ }^{\circ}$ 452, Buenos Aires, marzo 2005, pp. 6-15. Teresa Suárez expresa que el obispo de Buenos Aires, don A. Manuel Antonio de la Torre, en su visita a Santa Fe en 1764, recrimina a los sacerdotes por permitir velorios -en especial los de niños- que se extienden durante varios días y noches, y donde se realizan juegos, bailes y fandangos, y se producen borracheras, empleándose «lloradoras lamentatrices mulatas que gritan en estudio», aparentemente una costumbre india de alquilarlas para tal fin. Teresa SuÁREZ, «El discurso del morir...», cit., p. 86. Un panorama similar en lo que se refiere a los velorios de párvulos nos presenta María Elena Barral para la campaña bonaerense tardocolonial. María Elena BARRAL, De sotanas por la Pampa..., cit., pp. 192-194.

Hispania Sacra, LX

122, julio-diciembre 2008, 597-633, ISSN: 0018-215-X 
tolicismo, una forma de religiosidad popular, pero que quizá no alcanzaría para hablar de un sincretismo entre la religión católica y los diversos cultos provenientes de África, como «el sincretismo por correspondencia dioses-santos»señalado por Bastide para algunas regiones de América como Brasil, Cuba, Trinidad y Haití1 121 .

\section{OBSERVACIONES FINALES}

Si bien morir ab intestato parecía ser la regla y no la excepción para el segmento negro del Buenos Aires de fines del siglo XVIII y principios del siguiente, los testamentos de morenos y pardos encontrados nos ilustran sobre una variedad de aspectos socio-económicos, demográficos, culturales, religiosos atinentes al grupo, al punto de convertirse en una fuente sumamente rica para ensayar estudios como el que nos ocupa.

Hemos comprobado que los testadores «de color», aunque numéricamente representan una pequeña parte de la comunidad afroporteña, son aquellos que mejor se adaptaron a la sociedad en la cual estaban inmersos, aunque tibiamente integrados. Sabemos que fueron propietarios de bienes raíces e, incluso, de esclavos. En todo caso, hay, en el acto de testar, un marcado sentido religioso que se manifiesta desde la invocación inicial hasta el exordio espiritual, es decir la protesta de fe católica, la búsqueda de intercesores y el encomendamiento del alma, pasando por el reparto de los bienes materiales a través de la limosna, dimanada de la caridad, vía para expiar los pecados ${ }^{122}$.

Si bien la mayoría de los estudiosos de la negritud están de acuerdo en que la aculturación ocurrió en todas partes, más allá de este punto de partida básico, están los que acentúan la continuidad de las culturas nacidas en África, poniendo el énfasis en la resistencia cultural, y los que subrayan la criollización de las culturas afroamericanas, priorizando la adaptación cultural.

Este último parece haber sido el caso de Buenos Aires. Todos los afroporteños estudiados, incluso los que habían sido desembarcados compulsivamente en los puertos del Plata, se afanaron por adaptarse a la sociedad en que vivían. Aprendieron un oficio, ahorraron dinero con su «esfuerzo personal», compraron su libertad, luego un terreno y construyeron su propia casa, o directamente encararon la compra de una vivienda, modesta en la mayoría de los casos, pero propia, y compraron esclavos; liberaron a su familia, y quizá lo más importante, aceptaron la religión del dominador, participando activamente en sus ritos y congregaciones.

${ }^{121}$ Roger BASTIDE, Las Américas Negras. Las civilizaciones africanas en el Nuevo Mundo, Madrid, 1969, capítulo 7.

122 María Isabel SEOAnE, Forma y contenido de los testamentos..., cit., pp. 6-7 y 33. 
Obviamente, esto no puede ser tan taxativo y uniforme si nos referimos a toda la población afroporteña, y es lícito especular que en el seno de la misma se practicaran ritos no muy ortodoxos desde el punto de vista de la liturgia católica. Sin embargo, la documentación hallada no es ni demasiado abundante, ni demasiado explícita al respecto ${ }^{123}$, permitiéndonos hablar más de un afrocatolicismo como expresión de religiosidad popular que de un sincretismo religioso, que, de haber existido, no parece haber tenido la pujanza desenvuelta en otras regiones de América.

En todo caso, y volviendo a nuestros afroporteños, es posible que tuvieran la necesidad de demostrar en forma persistente que habían abandonado las prácticas de su gentilidad y abrazado fervorosamente la religión de sus amos, a pesar de haber sido obligados a aceptarla. Aun cuando estuvieran lo suficientemente transculturados y comprometidos con el orden establecido, debían manifestar constantemente que ya no eran un peligro para la sociedad en la cual estaban insertos, pues siempre estaba presente el estigma de la infamante esclavitud y la idolatría ${ }^{124}$. Si estuvieron segregados, no fue por sus propios deseos, precisamente.

En síntesis, la lectura y análisis de los testamentos indicarían que hicieron todo aquello que debían para formar parte de la misma sociedad que los había esclavizados, admitiendo sin renuencias las pautas culturales que ésta determinaba.

${ }^{123}$ De todos modos, se debe tener en cuenta la pérdida de documentación; en efecto, Guillermo Furlong consigna una veintena de expedientes sobre las cofradías porteñas -algunas de las cuales albergaban a afrodescendientes, como las de San Benito, Rosario, Socorro, Jesús Nazareno y Montserrat, entre otras- que antaño estaban depositados en el Archivo de la Curia Metropolitana de Buenos Aires, y que fueron destruidos como consecuencia de los sucesos políticos de 1955. Guillermo FurLONG, S. J., Historia social y cultural del Río de la Plata (1536-1810). El trasplante social, Buenos Aires, 1969, p. 534.

${ }^{124}$ Carmen Mena García, «Religión, etnia y sociedad: cofradías de negros...», cit., p. 149. En ese sentido, es interesante destacar la «total integración en la vida religiosa de la ciudad» lograda por la cofradía de Nuestra Señora de los Ángeles o «de los negritos» de Sevilla hacia mediados del siglo XVII, cuando la población afro de Andalucía sufre, por diversos motivos - la mortandad ocasionada por la peste bubónica de 1649, la caída del comercio negrero luego de 1840 al separarse las coronas de España y Portugal (que era el principal abastecedor de mano de obra esclava) y la crisis económica general de la península que impedía o al menos dificultaba la compra de esclavatura-, una sensible baja. Precisamente, según el análisis de Isidoro Moreno, el descenso del número de afro-sevillanos alejaba el riesgo de posibles rebeliones de los estratos inferiores de la sociedad, y dado que aquéllos «estaban ya fuertemente transculturados, al ser muchos de ellos hijos o hijas de otros morenos que habían vivido toda su vida en Sevilla o en otros lugares de Andalucía», estaba relativamente allanado el camino hacia una mayor integración social. Todo ello se vio reflejado en el «blanqueamiento» de la asociación, que comenzó a aceptar entre sus filas a personas de raza blanca. Carmen Mena García, «Las Hermandades de Sevilla y su proyección americana...», cit., pp. 136-137.

Hispania Sacra, LX

122, julio-diciembre 2008, 597-633, ISSN: 0018-215-X 
Apéndice documental: Testamentos de afroporteños

\begin{tabular}{|c|c|c|c|c|c|}
\hline Apellido y nombres & Calidad & Día & Mes & Año & Fuente \\
\hline Aguirre, Manuel & Negro & 6 & 11 & 1837 & r. $7,1836-1837$, f. $98 \mathrm{v}$. \\
\hline Alisa y Urien, José & Negro & 30 & 10 & 1851 & r. $7,1850-1851$, f. 267 \\
\hline Allende, Josefa & Parda & 12 & 2 & 1776 & r. 6,1776 , f. $44 \mathrm{v}$. \\
\hline Allende, María & Parda & 18 & 7 & 1780 & r. 6,1780, f. $226 \mathrm{v}$. \\
\hline Almada, María & Negra & 19 & 11 & 1849 & r. 2,1849 , f. 548 \\
\hline Almeyra, María Feliciana & Negra & 26 & 3 & 1844 & r. 2,1844 , f. 254 \\
\hline Altolaguirre, Bartola & Negra & 16 & 3 & 1849 & r. 2,1849, f. 137 \\
\hline Arandia, Juan José & Negro & 18 & 7 & 1860 & r. 2,1860 , f. 208 \\
\hline Arce, María de los Dolores & Parda & 12 & 5 & 1815 & r. 3,1815 , f. $104 \mathrm{v}$. \\
\hline Ascuénaga, Francisco & Negro & 16 & 2 & 1849 & r. 4,1849 , f. $52 \mathrm{v}$. \\
\hline Ascuénaga, María Francisca & Negra & 19 & 6 & 1786 & r. 6,1786, f. $265 \mathrm{v}$. \\
\hline Asencio, Francisco & Negro & 13 & 5 & 1825 & r. $6,1824-25$, f. $453 \mathrm{v}$. \\
\hline Astorga, Pedro & Indio & 19 & 3 & 1789 & r. 2,1789, f. 155 \\
\hline Avad, Rosa & Negra & 29 & 10 & 1849 & r. 8,1849 , f. $154 \mathrm{v}$. \\
\hline Bargas, María Teresa de & Negra & 7 & 9 & 1779 & r. 5,1779, f. 258 \\
\hline Bargas, María Teresa de & Negra & 5 & 11 & 1788 & r. 5,1788 , f. $330 \mathrm{v}$. \\
\hline Basavilvaso, Antonio & Negro & 26 & 6 & 1840 & r. $3,1840-1841$, f. $74 \mathrm{v}$. \\
\hline Belen, Baleriana & Negra & 28 & 12 & 1846 & r. 8,1846, f. 130 \\
\hline Betolasa, María Josefa & Negra & 27 & 7 & 1803 & r. 2,1803 , f. 318 \\
\hline Breques, Francisca & Negra & 1 & 3 & 1847 & r. $5,1846-1847$, f. $29 \mathrm{v}$. \\
\hline Buceta, Juan & Negro & 7 & 7 & 1851 & r. 5,1851, f. 443 \\
\hline Caitio, Mariana & Negra & 18 & 11 & 1850 & r. 2,1850, f. $507 \mathrm{v}$. \\
\hline Calderón, Elías & Negro & 10 & 6 & 1845 & r. 2,1845 , f. 332 \\
\hline Carmona, Juana Bentura & Parda & 30 & 11 & 1811 & r. 3, 1811, F. 391v. \\
\hline Carranza, Gregoria & Parda & 23 & 10 & 1768 & Sucesión 8142 \\
\hline Castellanos, Antonio & Negro & 22 & 11 & 1827 & r. 4,1827 , f. $519 v$. \\
\hline Cerna, Catalina & Negra & 9 & 2 & 1848 & r. 2,1848, f. $46 v$. \\
\hline Corpet, Diego & Negro & 15 & 4 & 1859 & r. 3,1859 , f. 264 v. \\
\hline Cueli, Micaela & Parda & 21 & 12 & 1830 & r. 8,1830, f. $233 \mathrm{v}$ \\
\hline Díaz, Cayetano & Negro & 11 & 12 & 1750 & Sucesión 5559 \\
\hline Díaz, Juana Catalina & Parda & 6 & 12 & 1821 & r. 3,1821, f. 198 \\
\hline Duarte, Isidro & Pardo & 16 & 9 & 1831 & r. 4, 1831-1832, f. 218 \\
\hline Duarte, Manuel & Negro & 10 & 10 & 1846 & r. $5,1846-1847$, f. 62 v. \\
\hline Durán, Victoria & Parda & 16 & 1 & 1801 & r. $2,1800-1801$, f. 32 \\
\hline Falcón, Ignacio & Negro & 18 & 6 & 1768 & r. $6,1768, f .176$ \\
\hline Falcón, Ignacio & Negro & 17 & 1 & 1793 & r. 6,1793 , f. $20 \mathrm{v}$. \\
\hline Fernández, Ramona & Parda & 29 & 1 & 1848 & r. $7,1848-1849$, f. $5 \mathrm{v}$. \\
\hline Ferreyra, María Francisca & Parda & ¿? & ¿? & 1812 & Sucesión 5689 \\
\hline García López, Antonio & Negro & 11 & 7 & 1843 & Sucesión 5929 \\
\hline
\end{tabular}




\begin{tabular}{|c|c|c|c|c|c|}
\hline Apellido y nombres & Calidad & Día & Mes & Año & Fuente \\
\hline González, Cayetano & Negro & 27 & 5 & 1834 & r. 1,1834 , f. 112 \\
\hline González, Francisco & Negro & 18 & 11 & 1852 & r. 2,1852, t. 2, f. 1161 \\
\hline González, Jacinto & Negro & 28 & 6 & 1762 & r. 2,1762 , f. 102 v. \\
\hline Goyena, José & Negro & 27 & 5 & 1834 & r. 8,1834 , f. 63 \\
\hline Gutiérrez, Manuel & Pardo & 1 & 6 & 1813 & r. 7,1813, f. 72 \\
\hline Higuera, María Josefa de la & Parda & 12 & 10 & 1847 & r. 8,1847, f. 136 \\
\hline Isabel & Negra & 23 & 12 & 1811 & r. 6,1811, f. 232 \\
\hline Ituvat, Escolástica & Negra & 11 & 7 & 1824 & r. $2,1824-25$, f. 202 v. \\
\hline Lavalle, Joaquín & Negro & 24 & 11 & 1837 & r. $3,1835-1837$, f. 125 \\
\hline Liceo, María del Carmen & Negra & 29 & 10 & 1838 & r. $5,1838-1839$, f. 129 \\
\hline Lima, Catalina & Negra & 7 & 3 & 1860 & r. 8,1860 , f. $46 \mathrm{v}$. \\
\hline López, Isabel & Negra & 12 & 5 & 1842 & r. 2,1842 , f. $219 v$ v. \\
\hline López, José Mariano & Negro & 20 & 3 & 1841 & r. 4,1841 , f. $71 v$. \\
\hline Luque, María Josefa de & Parda & 1 & 12 & 1768 & Sucesión 6724 \\
\hline Manrique, Asencia & no indica & 4 & 9 & 1789 & r. 6,1789 , f. $194 \mathrm{v}$. \\
\hline Mansilla Gaete, María & Parda & 16 & 9 & 1794 & r. $3,1794-1795$, f. $117 \mathrm{v}$. \\
\hline Martínez, María Luisa & Negra & 18 & 7 & 1851 & r. $7,1850-1851$, f. 152 \\
\hline Martínez, Mariana & Negra & 21 & 1 & 1834 & r. $4,1833-1834$, f. 11 \\
\hline Maza, Carmen & Negra & 7 & 5 & 1860 & r. 9,1860, f. 118 \\
\hline Mendiolara, María de los Santos & no indica & 1 & 3 & 1841 & r. 2,1841 , f. $119 v$ v. \\
\hline Navarrete, Juan Antonio & Pardo & 8 & 7 & 1793 & r. 6,1793 , f. 232 \\
\hline Navarro, Mateo & Negro & 7 & 2 & 1859 & r. 1,1859, f. 59 \\
\hline Núñez, Feliciano & Parda & 4 & 7 & 1764 & r. 5,1764 , f. $175 \mathrm{v}$. \\
\hline Padín, Josefa & Negra & 2 & 1 & 1834 & r. $4,1833-1834$, f. 1 \\
\hline Palacios, María & Negra & 22 & 8 & 1778 & r. $3,1777-1778$, f. 619 \\
\hline Palacios, Rosa & Negra & 30 & 5 & 1810 & r. 3,1810 , f. 216 \\
\hline Pan y Agua, María Antonia & Negra & 19 & 2 & 1851 & r. $3,1850-1851$, f. $40 \mathrm{v}$. \\
\hline Patria, Joaquina de la & Negra & 11 & 9 & 1844 & r. 4,1844 , f. 273 \\
\hline Paz, Catalina & Parda & 6 & 10 & 1840 & r. $5,1840-1841$, f. $130 \mathrm{v}$. \\
\hline Pessoa, Fermín de & Pardo & 24 & 11 & 1758 & r. $4,1759-1760$, f. 477 \\
\hline Pich de Marquez, Rufina & Negra & 19 & 5 & 1859 & r. 1,1859 , f. 360 \\
\hline Pinedo, Juana & Negra & 21 & 5 & 1798 & r. 3,1798 , f. $206 \mathrm{v}$. \\
\hline Portela, Josefa & Negra & 14 & 8 & 1837 & r. 2,1837 , f. $404 \mathrm{v}$. \\
\hline Preciado, Pedro-Igarzábal, Teresa & Negros & 15 & 9 & 1813 & r. 3,1813 , f. $299 \mathrm{v}$. \\
\hline Quisongó y Rosas, Cipriano & Negro & 12 & 3 & 1860 & r. 2,1860, f. $86 \mathrm{v}$. \\
\hline Ramírez, Luisa & Negra & 15 & 6 & 1852 & r. 7,1852, f. 214 \\
\hline Rico, José & Negro & 20 & 1 & 1847 & r. 2,1847, f. 34 \\
\hline Rivas, Pedro Nolasco & Pardo & 22 & 6 & 1818 & r. 3,1818 , f. 142 \\
\hline Rodríguez, Isabel & Negra & 26 & 3 & 1858 & r. 5,1858 , f. $141 \mathrm{v}$. \\
\hline
\end{tabular}

Hispania Sacra, LX

122, julio-diciembre 2008, 597-633, ISSN: 0018-215-X 


\begin{tabular}{|l|l|r|r|l|l|}
\hline Apellido y nombres & Calidad & Día & Mes & Año & \multicolumn{1}{|c|}{ Fuente } \\
\hline Rojas, María Mercedes & Parda & 17 & 10 & 1824 & r. 7, 1824-1825, f. 186v. \\
Romero, Juan Bautista & Pardo & 3 & 12 & 1827 & r. 4, 1827, f. 542 \\
Rosales, Constancia & Negra & 18 & 11 & 1856 & r. 3, 1856, f. 573 \\
San Martín y Gutiérrez, María Micaela & Parda & 10 & 3 & 1802 & Sucesión 8140 \\
Sánchez, Manuel & Negro & 22 & 12 & 1853 & r. 6, 1853, f. 369v. \\
Sarratea, Manuel Dolores & Negro & 17 & 11 & 1810 & r. 3, 1810, f. 436v. \\
Sarratea, Manuel Dolores & Negro & 20 & 11 & 1843 & r. 2, 1843, f. 561v. \\
Semo, Ana María & Negra & 28 & 6 & 1849 & r. 1, 1849, f. 462 \\
Sevicos, María & Negra & 20 & 7 & 1791 & Sucesión 8418 \\
Solveira, Manuel & Negro & 30 & 6 & 1830 & r. 2, 1830, f. 150 \\
Sosa, José Pascual & Negro & 6 & 12 & 1814 & r. 3, 1814, f. 279v. \\
Sosa, María del Carmen & Parda & 4 & 5 & 1759 & Sucesión 8411 \\
Tapia y Alarcón, Lucas & no indica & 10 & 5 & 1792 & r. 6, 1792, f. 162v. \\
Tompson, Francisco José & Negro & 6 & 6 & 1778 & r. 6, 1778, f. 146v. \\
Vicuña, Margarita & Parda & 19 & 2 & 1787 & r. 6, 1787, f. 62 \\
Vivar de la Rosa, Joaquina & Negra & 24 & 3 & 1844 & r. 5, 1844-1845, f. 38v. \\
Wrigth, Petrona Catalina & Negra & 18 & 10 & 1854 & r. 5, 1853-1854, f. 469v. \\
\hline
\end{tabular}

Fuente: Archivo General de la Nación, Protocolos Notariales y Sucesiones 